\title{
Screening European market potentials for small modular wastewater treatment systems - an inroad to sustainability transitions in urban water management?
}

\section{Keywords}

decentralised wastewater treatment, economies of scale, infrastructure planning, geographical information system, population density

\section{Abstract}

Urban water management represents a core economic sector exposed to global water-related challenges. Recently, small modular system configurations have been identified to enable a potential sustainability transition in this lasting and rather conservative sector. The identification of current market potentials of decentralised wastewater treatment is a first step to assess whether decentralised treatment technologies could potentially be deployed on a larger scale in Europe, which would allow current decentralised wastewater treatment technologies to develop and mature. The paper elaborates a method to assess the market potential for decentralised wastewater treatment systems by starting from a raster-based geospatial modelling framework, to determine the optimal degrees of centralisation for the case of Switzerland. The resulting market potential is shown to be twenty times higher than the current market share of decentralised systems. In order to extrapolate these findings to other countries, the calculated optimal degrees of centralisation were correlated with different spatial density measures to determine a reliable and widely available proxy: population density. Based on this indicator, the European market potentials for decentralised treatment systems are estimated to be about 100 '000 units per annum serving around 35 million population equivalents. The paper concludes by discussing implications for future sustainability transitions in urban water management by large-scale installation of small modular wastewater treatment systems.

This document is the accepted manuscript version of the following article: Eggimann, S., Truffer, B., Feldmann, U., \& Maurer, M. (2018). Screening European market potentials for sma11 modular wastewater treatment systems - an inroad to sustainability transitions in urban water management? Land Use Policy, 78, 711-725. https://doi.org/10.1016/j.1 landusepo1.2018.07.031 


\section{Introduction}

With investments of about $1 \%$ of the global gross domestic product (OECD, 2006) and an estimated return on investment of US\$5.5 per US\$ invested (Hutton and Haller, 2004), urban water management (UWM) infrastructure constitutes one of the major assets of the built environment and contributes fundamentally to human and environmental health (UN WWAP, 2017). To cope with multiple water-related challenges of global environmental change, the UWM sector needs to reconsider its former success conditions. What is at stake is the management of a sustainability transition which will depend on a whole series of innovations both in the technological and institutional setup of the sector, i.e. a renewal of its 'socio-technical regime' (Geels, 2006; Markard, Raven and Truffer, 2012;;Martínez Arranz, 2017). Sustainability transitions can be defined as "long-term, multi-dimensional, and fundamental transformation processes through which established socio-technical systems shift to more sustainable modes of production and consumption" (Markard, Raven and Truffer, 2012). The currently dominant socio-technical regime of the UWM sector can be considered to be quite uniform across the world (Fuenfschilling and Binz, 2018). Technologically, it consists of long-living network infrastructures (i.e. drinking water distribution pipes and sewers) and centralised water and wastewater treatment plants and it is predominantly supported by civil engineering expertise. These characteristics have led to strong technological path-dependencies over the past decades (Thomas and Ford, 2005). At the same time, a neatly aligned institutional and organisational governance structure has emerged, leaving the sector with a conservative take when it comes to dealing with innovative concepts and approaches (Kiparsky et al., 2013). As a consequence, we postulate that the UWM sector is confronted by an equivalent of the carbon lock-in in the energy sector (Unruh, 2000): an over reliance of long living centralised infrastructures, which prevents alternative, potentially more sustainable technological options to develop and mature.

Different key UWM services such as the provision of safe drinking water, urban hygiene, water pollution control and the management of urban runoff (effluent and storm water) are closely linked to and interdependent to each other (Larsen and Gujer, 1997), e.g. when storm water runoff and domestic wastewater are transported in combined sewers. The aim of this 
paper is to identify possible pathways for today's wastewater treatment infrastructures to transform into more sustainable directions by opting for the most sustainable mix of centralised and decentralised wastewater treatment infrastructure. The planning context of wastewater infrastructures is challenging as ideally different sub-systems and its interdependencies need to be considered (Fagan, Reuter and Langford, 2010; Makropoulos and Butler, 2010; Guo and Englehardt, 2015; Kavvada, Nelson and Horvath, 2018). The focus of this paper is limited to wastewater in order to cope with the complexity of the modelling task and because we are optimising for a "green-field" approach, where storm water is best treated and transported separately (cf. Section 2.2).

Even though the centralised regime has contributed to the eradication of diseases such as typhoid and cholera (O'Flaherty, 2005), it is confronted with increasing critics when it comes to its longer term sustainability prospects. It often turns out to be associated with considerable ecological and economic costs, due to sewer overflows, leaking pipes or water scarcity and it often results in a financial burden for local communities (Daigger, 2007; Bahri, 2012; Braga et al., 2014; Gawel, 2015; Sadoff et al., 2015; UN-WWAP, 2015; Hall et al., 2016). In many settings around the world, particularly outside an OECD context, the centralised approach is problematic, as complexity of centralised infrastructure investments generally requires 'significant complementary institutional capacity (and financial resources) for management, operations, and maintenance' (Sadoff et al., 2015).

The degree of dominance of the centralised socio-technical regime is geographically varied. Many countries have developed very high penetrations of their centralised systems: the United Kingdom, Switzerland or the Netherlands, for instance, have enforced central connection rates close to $100 \%$ (OECD, 2015, Eurostat, 2017). Lower connection rates are found in other OECD countries where considerable segments of the population are served by more or less functional decentralised wastewater treatment systems. A notable example is Japan, where the development of small-scale treatment units known as Johkasou results in a current connection rate of 78\% (Gaulke, 2006; OECD, 2010, 2015; Yang et al., 2011). 
The terms "centralised" and "decentralised" wastewater treatment systems need to be defined in the context of this paper, as they are used quite differently in literature (Sharma et al., 2013): Whereas centralised treatment is used to describe a system based on large-scale wastewater treatment plants and sewer based transportation, the key feature of decentralised systems is treatment of wastewater close to the point of origin (Wilderer and Schreff, 2000). A whole continuum of spatial arrangements of treatment scales are conceivable (Ambros, 1996; Libralato, Volpi Ghirardini and Avezzù, 2012). We use the term 'hybrid systems' for combined centralised and decentralised systems. By decentralised treatment, we understand small-scale mechanical-biological treatment plants, i.e. treatment technologies offering the same or very similar performance to those of centralised treatment. Because no clearly quantifiable distinction exists in terms of scale (or "closeness") to distinguish between centralised and decentralised treatment, it is necessary to specify this for a given context (which is provided for a Swiss context in Section 2). Therefore, we us the terminology of "small modular" as outlined by (Dahlgren et al., 2013) for referring to fully matured decentralised wastewater treatment systems which are characterised by modularisation, automation and mass production. This terminology is used to clearly distinguish between fully automated decentralised systems where high economies of numbers are achieved in manufacturing and where total system costs are dominated by treatment instead of transportation (cf. Dahlgren et al., 2013).

Conventional decentralised approaches are often seen as a mere technological stopgap, with a far lower performance than centralised systems. In particular, they are considered as too expensive, performing worse in terms of treatment capacity, essentially unreliable and hard to regulate (McDonald et al., 2014; Sadoff et al., 2015; Huskova et al., 2016). Outside of OECD countries, connection rates to the centralised system have remained very low, with little prospect of increasing anytime soon. Also, decentralised systems are often unable to provide safe sanitation services, which is a particularly pressing problem in developing countries (Lüthi et al., 2011). However, membrane-based systems can achieve high levels of performance across a wide range of treatment plant sizes (Fane and Fane, 2005; Peter-Varbanets et al., 2009; Zodrow et al., 2017). Furthermore, recent developments in the realm of modular system configurations taking advantage of the latest information and sensor technologies may counter 
many of these assumed weaknesses: Excessive personnel costs may be avoided due to the availability of low cost automation and remote monitoring (Dahlgren et al., 2013). This would enable centrally operated contracting schemes for large fleets of decentralised systems and by this guarantee similar levels of technical reliability like todays centralised systems (Larsen, Udert and Lienert, 2013; Larsen et al., 2016). One good example showing the success and advantages of such a contracting scheme is for example provided for a German context by Hiessl et al. (2010). In particular, recent developments in pathogen monitoring suggest that system reliability may be increased substantially by autonomous control systems which may prove far more effective than traditional monitoring and control protocols (Hering et al., 2013). The shift towards such small modular UWM infrastructures can also be witnessed in realms of water disinfection, water reuse, desalination and resource recovery (Friedler and Hadari, 2006; Alnouri, Linke and El-Halwagi, 2015; Shahabi et al., 2015; Guo, Englehardt and Fallon, 2016).

However, the successful further development and maturing of decentralised systems depends on a vast array of interrelated socio-technical innovation processes. Their successful introduction depends on whether substantial entry markets can be identified and whether industry, utilities and regulators will actually formulate corresponding innovation strategies. A number of challenges have to be overcome along the way to fully functional and cost-effective small modular systems such as reliable system operation with comparable performance level to centralised treatment, the exploitation of economies of learning and scale in manufacturing to substantially decrease costs or the development of appropriate management and governance structures (Hoogma, 2002). A sustainability transition in the urban water sector will only be conceivable if these challenges can be tackled in a balanced way. This task therefore resembles a systemic innovation process rather than a static optimisation task where an suitable technology can be selected from the shelf (Truffer et al., 2013).

One crucial precondition for these innovation processes to happen is to identify the overall market potentials of current decentralised wastewater treatment systems in terms of numbers of units demanded for sale per annum. By assessing the market potential, we mean to estimate an order of magnitude of units that could be sold on a per annum basis for a given region. However, this number provides only a rough estimate of what companies might be able to sell in 
141 these markets in the future. The actual market volume may depend on all sorts of efforts that have to be spent to penetrate the market such as marketing costs, adaptations to local rules

143 and regulations or the diversity of market segments. Our estimated market potential can only be taken as an indication for informing future firm strategies, not as a reliable prediction of future business volumes. Furthermore, we want to clarify that we base our estimations predominantly on the market in rural and peri-urban regions. This is however not to say that decentralised water treatment could only be applied in these contexts (Nolde, 2012; Li et al., 2013; WERF, 2018). In that sense, our estimates will rather be at the lower end of the spectrum. Finally, we have to note that our analysis estimates market potentials with respect to cost characteristics related to techno-economic assumptions (see Section 2.2). The market potential of decentralised wastewater treatment systems however differs, depending on how different aspects of a market are constituted such as its end user profiles, ownership models of the technology or taxation. Given the scope of this paper, we cannot provide a complete analysis of all these different market related aspects on a European scale but only mention the influence of some key elements in the discussion. Also, the question on how or whether these market potentials may be reaped needs to be discussed elsewhere.

Given the high degree of regional variety of current market shares of decentralised systems, a benchmark needs to be defined across different countries. Conceptually, this is derived by specifying the optimal degree of centralisation in a given region (Downing, 1969; Converse, 1972; Abd El Gawad and Butter, 1995; Starkl et al., 2012; Zeferino, Cunha and Antunes, 2012; Lee et al., 2013; Poustie et al., 2014; Arora et al., 2015; Van Afferden et al., 2015; Baron et al., 2015; Sapkota et al., 2016; Wilderer et al., 2016; ). The degree of centralisation can be operationalised as the percentage of the population in a given region that is connected to a central wastewater treatment plant (WWTP), assuming that all other households are served by a decentralised option, i.e. assuming that all households are treated. The optimum degree of centralisation can be defined with respect to a set of different environmental, social or economic criteria. We however limit ourselves to a single-optimisation optimisation approach and define the optimal degree of centralisation with respect to only minimising for overall costs of treating wastewater in the region. To allow for small modular systems to replace connections to the 
centralised system, the treatment performance of the overall system must be comparable.

Whereas for example nutrient recovery, energy implications (e.g. generation of biogas) or water reuse options differ for centralised and decentralised systems and may be inherently linked to either system, the provision of save sanitation services (i.e. high treatment quality) is a necessary criterion for either system. Thus, not only the treatment plant performance, but also any losses during transportation (e.g. combined sewer overflows) would need to be considered. The validity of this assumption obviously depends on different factors such as technological developments, an appropriate technological choice, or a successful system operation and maintenance. Nevertheless, there are no fundamental reasons why this functional equivalence cannot be achieved (Hillenbrand, T.; Hiessel, 2016). . Additionally, we assume that the cost characteristics of both system types can be derived from current offerings found on the market for wastewater treatment technology. We thus abstract from potential effects on cost due to mass production or the higher complexity of future small modular systems. Based on these assumptions, Eggimann et al. (2016a) recently proposed a full cost assessment framework for a given region. They follow a geospatially explicit modelling approach, which heuristically optimises for least-cost infrastructure layouts considering topography and the full range of WWTPs in terms of sizes. This approach is extended in the following section to assess the market potentials for small modular systems in an entire country (Switzerland) and the whole of Europe. The challenge of this upscaling methodology is that the original approach does not scale well in computational terms (NP-hard) and has only been applied to regions of up to a few tens of thousands population equivalents $\left(P E^{1}\right)$. . As a consequence, we were forced to formulate a multi-step screening approach for assessing the European market potentials.

To conduct this analysis, the existing regional cost assessment model is scaled up to the national scale of Switzerland (Section 2). Section 3 correlates the estimated Swiss market potentials with different density measures, thus providing a suitable proxy for extrapolating market potentials for Europe (Section 4). This leads to the discussion as to whether these market potentials could provide suitable entry markets for small modular systems in view of future sustainability transitions in UWM (Section 5). Section 6 concludes with an outlook on the implications of the analysis presented here for global environmental change in the water sector. 


\section{Estimating market potentials on a national scale}

The market potentials of small modular wastewater treatment for the whole of Switzerland is estimated in three-steps. Firstly, we define the terms centralised and decentralised for a Swiss context (Section 2.1) and provide the system boundaries (Section 2.2). Secondly, an existing geospatial optimisation model is applied for defined raster cell catchments covering Switzerland to estimate the optimal degree of centralisation within each cell (Section 2.3). This model application provides the number of decentralised and centralised wastewater treatment plants in each raster cell and thus the number of total PE served by centralised or decentralised treatment systems within each cell. Thirdly, the results of all raster cells are aggregated for the whole of Switzerland to calculate an overall potential national market share and correlate the results with alternative measure for population density (Section 2.4).

\section{1 (De)centralised treatment in Switzerland}

. The terminology (centralised or decentralised) differs across countries with respect to the treatment unit size and needs therefore to be specified: In Switzerland, treatment systems up to 200 PE are generally characterised as small-scale systems (VSA, 2016). We use this generic definition, to distinguish between centralised and decentralised treatment and categorise WWTPs into different classes depending on their treatment capacity (Table 1). Treatment systems from category A (maximum 20 PE) typically treat wastewater for a single- (or multiple-) -family household ("micro-treatment") and are generally manufactured in the form of packaged treatment plants. Category B treatment systems are more focused on the neighbourhood and service a cluster of households with maximum 200 PE. Treatment systems from category A and category B are considered as decentralised systems for this study, whereas treatment systems with higher capacities than 200 PE are considered as centralised systems. Systems from category A and B are considered possible candidates for small modular systems. Nearly the whole Swiss population (>97\%) is connected to centralised WWTPs (UN, 2015). The country currently has $\sim 760$ large WWTP catchments, which have been defined in terms of their population density, topographic situation and administrative borders (BAFU, 2016). The rest of the population is served by $\sim 3,000$ decentralised treatment systems (Swiss Water Pollution Control Association, 2006). 


\begin{tabular}{|c|c|c|c|}
\hline & $\begin{array}{l}\text { WWTP } \\
\text { category }\end{array}$ & PE & $\begin{array}{r}\text { No. of } \\
\text { installations }\end{array}$ \\
\hline Decentral & $\begin{array}{l}A \\
B\end{array}$ & $\begin{array}{r}\leq 20 \\
20-200\end{array}$ & $-3,000$ \\
\hline Central & C & $>200$ & $\sim 760$ \\
\hline
\end{tabular}

Table 1: Classification of treatment systems with respect to capacity in a Swiss context and the number of currently installed systems.

\subsection{System Boundaries}

The conceptual modelling approach chosen to assess market potentials for (de)centralised wastewater treatment exclusively considers cost criteria and does not factor in the whole complexity of UWM planning. It in particular neglects political, social or regulatory conditions. In order to determine the overall sustainability performance of the compared systems, numerous advantages and disadvantages would have to be considered (Grant et al., 2012; Libralato, Volpi Ghirardini and Avezzù, 2012; Lee et al., 2013; Lienhoop et al., 2014; Morera et al., 2015; Cornejo, Zhang and Mihelcic, 2016; Kavvada et al., 2016). The optimisation is static and estimates optimal infrastructure layouts without considering former infrastructure investments. Furthermore, it is assumed that the system choice takes place in a 'green field' context, i.e. no stranded investments have to be taken into account. Considering existing centralised infrastructures would need a different dynamic 'transitory' approach requiring in-depth knowledge about the current state of the infrastructure and investment behaviour of utilities over time. This is however case specific and practically intractable in terms of data collection on a large scale. Because of neglected issues of stranded investments and ignoring sunk costs, this analysis overestimates the potential of decentralised infrastructure (cf. Section 5.2). This overestimation is however minor and can be neglected. ${ }^{4}$ This limitation is less problematic in case of less developed wastewater infrastructure systems or in case of necessary infrastructure renewal.

For the same reasons, costs for specific network-based runoff systems and storm water removal are ignored. The integration of storm water into the wastewater system, also called combined systems, is mainly a legacy approach. Modern urban drainage proposes are much wider variety of options to deal with storm water (see e.g. Fletcher et al., 2015), that relies on 
the separation of the two water streams. For our approach we assume that our treated wastewater can be integrated into existing urban drainage schemes and ignore the outdated notion of using the wastewater transport network for managing storm water.

Finally, this analysis focuses on domestic wastewater and neglects potential synergies with water reuse schemes. Decentralised wastewater reuse is a reliable water source for alleviating (environmental) water scarcity in urban areas, e.g. for reducing urban heat-island effects (USNRC, 2012). It is therefore unclear whether our market potential estimation leads to an under- or overestimation, particularly in urban areas. Including industrial wastewater in the cost calculation may potentially result in a higher population equivalent density and thus higher degrees of centralisation if the industrial wastewater is similar in composition to residential wastewater and can be added to the centralised treatment system. However, in reality the picture is substantially more complicated, as many industries already have on-site treatment or pre-treatment facilities due to regulation, the specific nature of their wastewater or for purposes of water and product recovery (Patterson, 1985). Moreover, industries are generally concentrated in urban areas with a low decentralised market potential.

\subsection{Geospatial optimisation framework}

Urban water systems are being studied via a wide range of different modelling approaches (Bach et al., 2014). For this study, a heuristic algorithm for sewer network generation known as SNIP (Sustainable Network Infrastructure Planning) is used to estimate the optimal degree of centralisation of wastewater treatment on a national scale. In the present paper, no in-depth explanation of the algorithm is provided but a reference is made to Eggimann, Truffer and Maurer (2015), where the applied methodology is outlined in full detail. SNIP is a two-step techno-economic model designed to heuristically optimise the dimensioning, placement and number of WWTP with the aid of a methodology for shortest path-finding and agglomerative hierarchical clustering. The most cost-efficient wastewater infrastructure for serving households in a given region is modelled on the basis of different current $\operatorname{cost}^{2}$ and sewer-design parameters (see Eggimann, Truffer and Maurer, 2015 for full details). For each catchment for which SNIP is applied, the resulting system configuration may be a fully centralised system with one large wastewater treatment plant, hybrid system configurations consisting of small and 
large treatment plants or fully decentralised treatment systems constituted only by decentralised treatment plants. The optimisation considers transportation costs in sewers and treatment costs for the whole dimensional spectrum of central or decentral WWTPs. The costs calculations across the whole PE spectrum are taken from Swiss cost estimates of large scale treatment plants and from international cost literature of small-scale treatment systems, including UV disinfection and a drip disposal system (Eggimann, Truffer and Maurer, 2016b). The costs of future fully functional small modular systems are assumed to be equal to those of currently available decentralised treatment systems. This assumption could be challenged over the longer term: future systems may need additional features in terms of sensors and remotecontrol options. On the other hand, mass production is likely to lead to strong cost decreases in proportion to an expanding market size (Wilderer and Schreff, 2000; Adler, 2007; Hillenbrand et al., 2013). Only little literature is available which discusses potential future cost reductions for the wastewater sector. An exception is Hillenbrand (2009), who estimates future potential savings for a broad application of membrane based system to be about $30 \%$ under the assumption of a learning rate of $10 \%$. Learning curves are however a well-known phenomenon in many industry sectors (Mcdonald and Schrattenholzer, 2002):Contrasting potential cost reductions for other technologies such as photovoltaics or batteries in the energy sector shows that cost can potentially fall drastically (Mayer et al., 2015; Nykvist and Nilsson, 2015). The market potentials of current technological options are merely taken as a starting point or entry market for new, more innovative next-generation decentralised (i.e. small modular systems) options

In order to run SNIP on a national scale, several adaptations of the original algorithm were necessary to reduce the computational burden: the raster resolution of the underlying digital elevation model was changed from $25 \times 25$ to $100 \times 100$ metres and the original shortest path finding heuristic in the sewer path-finding procedure where no roads exist is replaced by a straight-line distance approximation.

To run SNIP, geographical and population data preparation is necessary: firstly, all buildings accommodating one or more flats are extracted from the Swiss federal register for buildings and dwellings published by the Federal Statistical Office (2006). Secondly, building outlines and 
311 heights are taken from Swissbuildings 1.0 (Federal Office of Topography swisstopo, 2006) in order to calculate the building volumes used. The Swiss population (Federal Statistical Office $\mathrm{BFS}, 2006)$ is then assigned with the aid of a volumetric population disaggregation method developed by Lwin and Murayama (2009). Thirdly, urban structure units are created to reduce the computational burden. This enables us to generalise the built environment in our case study into areas of a homogenous character (Wickop, 1998; Schiller, 2010).

To conduct the national screening analysis, Switzerland is partitioned by applying two different geospatial units, namely raster cells and WWTP catchments. This enables us to consider the sensitivity with respect to the choice of territorial unit of analysis. For each of the two geospatial partitions, we determine the optimal degree of centralisation and ignore any potential interlinkages between neighbouring units. For the raster-based analysis, we span a grid with a raster cell size of $7.2 \mathrm{~km}$ across the whole of Switzerland (Figure 1). This size is chosen to reflect the current average dimensions of Swiss WWTP catchments $\left(\sim 52.2 \mathrm{~km}^{2}\right)$. All raster cells are then clipped with areas with no data availability, containing about $7.8 \%$ of the total population. Additionally, all raster cells containing fewer than 300 PE are excluded from the analysis $(\sim 0.2 \%$ of the total population) ${ }^{3}$ (Figure 2). Therefore, additional potentials may be identified in these regions, and would need to be added to the current Swiss estimations. These neglected regions may have a high market potential for decentralised systems as they are located in less densely populated parts of Switzerland (cf. Fig. 2).

The modelling results are then aggregated to the Swiss cantons by assigning raster cells to the canton having the largest area within the cells. Finally, we generate scenarios to analyse the model sensitivity of SNIP: Instead of performing calculations with random model parameter perturbations, we varied the most important model parameter $\mathrm{f}_{\text {minslope }}$ for running the algorithm for the sewer-network generation to generate minimum and maximum scenarios in addition the standard configuration for parameter-space exploration (see results in Table 3). The sewer design parameter $\mathrm{f}_{\text {minslope }}$ is used to define the minimum slope of the simulated sewers. Larger parameter values result in sewers with steeper slopes and consequently results in deeper trench-depths and more pumping needs. This means that costs for the centralised system increase and thus more decentralised solutions are favoured. 


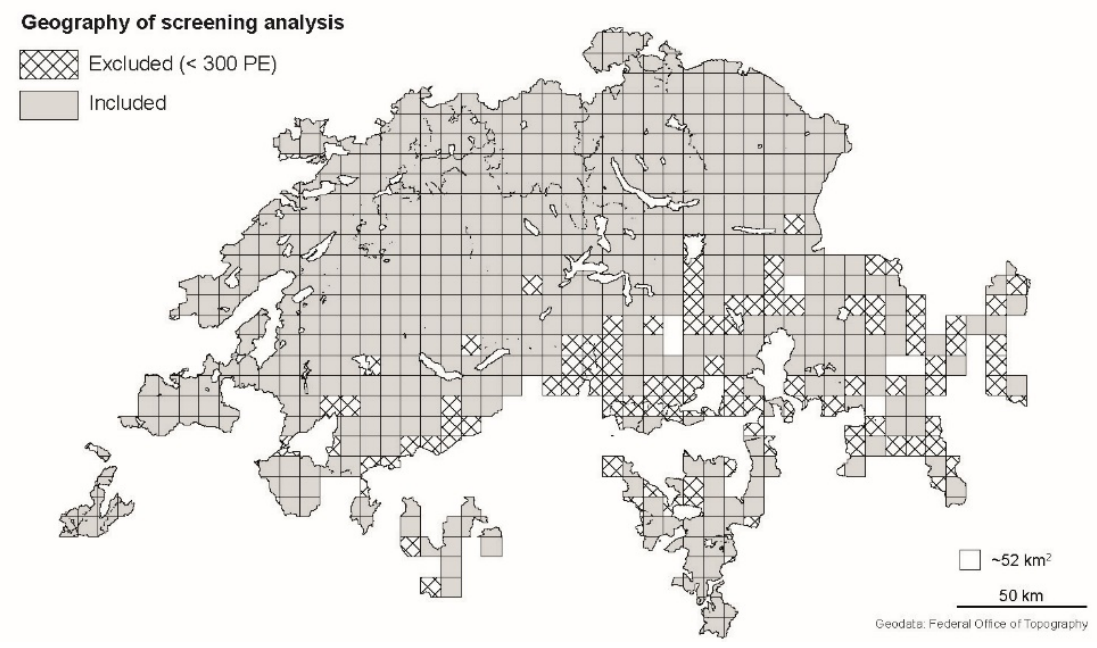

341 Figure 1: Raster-based partitioning of Switzerland $(n=127)$.

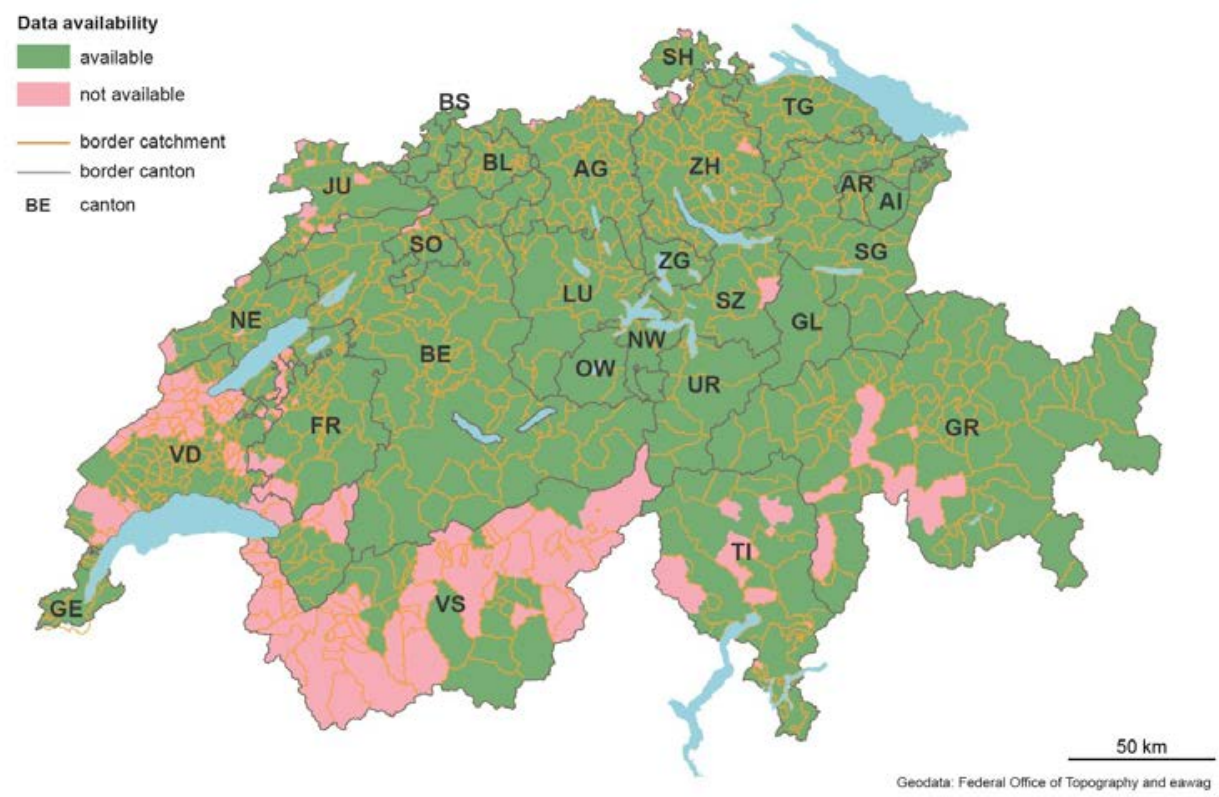

343 Figure 2: Overview of data availability and the administrative (geodata source: Swisstopo,

344 2015) and WWTP catchment boundaries (geodata source: Eawag, 2014) of Switzerland.

\subsection{Swiss market potential}

We asses market potentials across the whole spectrum of population density values with the outlined methodology in Section 2.2 in order to assess the relationship between population density and the market potential. The assessed market potentials of population density values in

349 Switzerland are classified into three classes (dc): rural, peri-urban and urban: however, there is no widely accepted definition of these classes (UNSTATS, 2016). Given the Swiss case study, these three density classes are defined by using a community-based classification produced by 
352

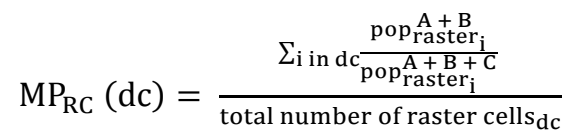

$\mathrm{MP}_{\mathrm{DC}}(\mathrm{dc})=\frac{\sum_{\mathrm{i} \text { in dc }} \text { pop }_{\mathrm{raster}}^{\mathrm{A}+\mathrm{B}}}{\text { total pop }} \mathrm{dc}$ living-condition characteristics (Table 2). categories defined in Table 1). (Equation 2):

the Federal Office for Spatial Development (2005), where different types of communities are distinguished statistically on the basis of their commuting, employment, tourism, housing and

\begin{tabular}{lr}
\hline Density classes & $\begin{array}{r}\text { Average population density } \\
{\left[\mathrm{PE} / \mathrm{km}^{2}\right]}\end{array}$ \\
\hline Federal Office for Spatial Development & \\
Centres & 1,347 \\
Peri-urban communities & 229 \\
Peripheral communities & 115 \\
Derived density class & \\
Urban & $>1,000$ \\
Peri-urban & $200-1,000$ \\
Rural & $<200$
\end{tabular}

Table 2: Average population densities of a Swiss community-based classification by the

Federal Office for Spatial Development (2005) and derived population density classes.

The raster cell and catchment-based assessment of market potentials allows us to define different spatial statistics. For the market potential based on raster cells $\left(\mathrm{MP}_{\mathrm{RC}}\right)$, a weighted sum is calculated for each density class ( $\mathrm{dc}=$ urban/peri-urban/rural) over all raster cells ( $\mathrm{i}_{\text {density class }}$ ) to obtain the average and mean market potentials (Equation 1) (A, B and $C$ are the WWTP

The market potential statistics based on the density classes $\left(\mathrm{MP}_{\mathrm{DC}}\right)$ are calculated as follows

Figure 3 shows the market potential for all Swiss raster cells, distinguished according to the three population density categories. A clear trend can be seen with higher average market potentials for increasing population densities. Whereas the calculated market potentials are on average highest for the rural category, we also find highest deviation for these densities. 


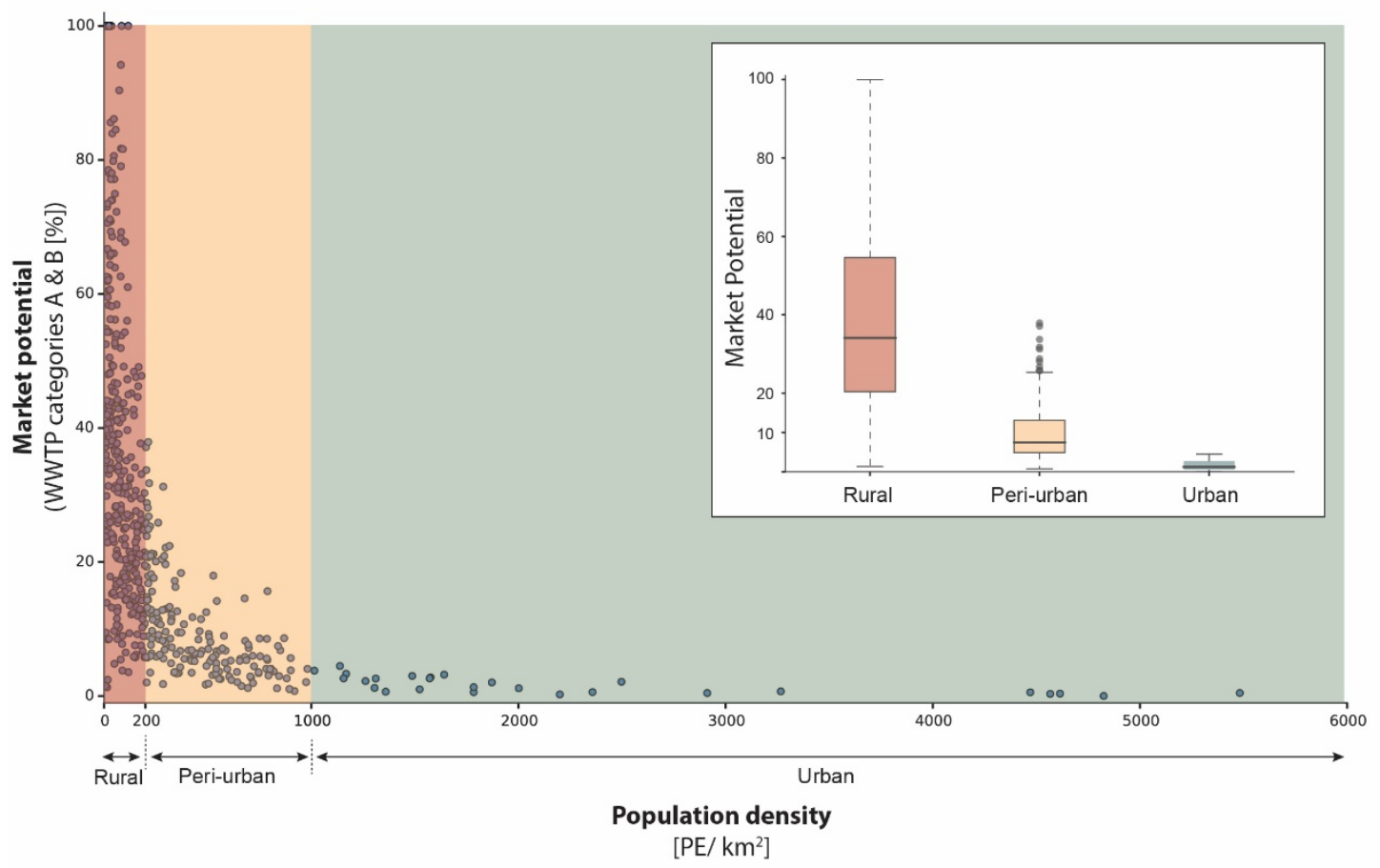

Figure 3: Raster-based screening for decentral wastewater treatment potentials for the standard scenario run. Boxplots for the three population density classes are provided in the inset figure.

\begin{tabular}{|c|c|c|c|c|}
\hline Density class & Rural & Peri-urban & Urban & Total \\
\hline Total Swiss population $(\mathrm{P})$ & $16.9(-)$ & $53.0(-)$ & $30.1(-)$ & 100 \\
\hline \multicolumn{5}{|l|}{ Spatial statistics } \\
\hline \multicolumn{5}{|l|}{ Density class-based $\left(\mathrm{MP}_{\mathrm{DC}}\right)$} \\
\hline WWTP category A and B & $31.2(0.97)$ & $7.8(0.57)$ & $1.2(0.10)$ & \\
\hline \multicolumn{5}{|l|}{ Raster cell-based $\left(\mathrm{MP}_{\mathrm{RC}}\right)$} \\
\hline Mean of WWTP category A and B & $41.2(0.75)$ & $10.1(0.68)$ & $1.6(0.11)$ & \\
\hline Median of WWTP category A and B & $34.1(0.72)$ & $7.5(0.66)$ & $1.2(0.14)$ & \\
\hline \multicolumn{5}{|l|}{ WWTP statistics $\left(P * M P_{D C}\right)$} \\
\hline Population in WWTP category A and B $[\%$ & $5.3(0.16)$ & $4.1(0.30)$ & $0.3(0.03)$ & $9.7(0.49)$ \\
\hline \multicolumn{5}{|c|}{ Number of WWTP calculated by the optimisation framework (Section 2.1) } \\
\hline Category A & 29,993 (399) & $16,446(599)$ & $1,234(59)$ & $47,673(1,057)$ \\
\hline Category B & $3,279(147)$ & 2,924 (275) & $263(28)$ & $6,466(450)$ \\
\hline Category C & $996(43)$ & $1,526(165)$ & $301(55)$ & $2,823(263)$ \\
\hline Category $\mathrm{A}$ and $\mathrm{B}$ & $33,272(546)$ & $19,370(873)$ & $1,497(86)$ & $54,139(1,505)$ \\
\hline
\end{tabular}
Table 3 shows the Swiss market potential in terms of the number of WWTPs differentiated by geographical contexts. The findings are as follows: according to the density class-based statistics, we calculate an optimum implying that $31.2 \%$ of the population living in rural areas 
411 (where $16.9 \%$ of the total Swiss population live) would be best served by decentralised systems.

412 Overall, this corresponds to $5.3 \%$ of the total Swiss population. A lower optimum is calculated

413 for the peri-urban areas with an overall market potential for decentralised wastewater treatment

414 of $7.8 \%$, and $1.2 \%$ in urban areas. These market potentials sum up to $9.7 \%$ of the total Swiss

415 population. A generally higher market potential is found for the raster cell-based statistics across

416 all density classes because fewer people generally live in less populated raster cells. In terms of

417 the total number of decentralised systems, an increase in the market potential by a factor of

418 almost 20 is calculated (from today's approximately 3,000 systems to a simulated 54,000 ). As

419 the potential is greatest in areas of low population density, where the per capita infrastructure

420 costs are also generally highest, an overall market potential of $\sim 10 \%$ is likely to represent a

421 large share of the overall economic costs of wastewater infrastructure investments in

422 Switzerland. 
Accepted in Land Use Policy

\begin{tabular}{|c|c|c|c|c|c|c|c|}
\hline \multirow{2}{*}{$\begin{array}{l}423 \\
424 \\
425\end{array}$} & \multirow[b]{2}{*}{ Country } & \multicolumn{2}{|c|}{ Extrapolated small modular market potential } & \multirow{2}{*}{$\begin{array}{l}\text { Currently no central treatment } \\
\text { Population [\%] }\end{array}$} & \multicolumn{3}{|c|}{$\begin{array}{r}\text { Annual number of small modular treatment units } \\
\text { with Swiss plant distribution ( } 88 \% \text { category A, } 12 \% \text { category B) }\end{array}$} \\
\hline & & Population [\%] & Population [PE] & & $10 \mathrm{PE}[\#]$ & $110 \mathrm{PE}[\#]$ & Total [\#] \\
\hline 426 & France & 10 & $5,689,000$ & 19 & 15,219 & 2,064 & 17,284 \\
\hline 427 & Germany & 6 & $5,050,000$ & 3 & 13,510 & 1,832 & 15,343 \\
\hline 428 & Poland & 10 & $3,858,000$ & 28 & 10,321 & 1,400 & 11,721 \\
\hline 429 & Italy & 6 & $3,428,000$ & 12 & 9,170 & 1,244 & 10,414 \\
\hline 430 & United Kingdom & 4 & $2,703,000$ & 0 & 7,230 & 980 & 8,211 \\
\hline 431 & Spain & 4 & $2,098,000$ & 2 & 5,613 & 761 & 6,375 \\
\hline 432 & Romania & 7 & $1,510,000$ & 55 & 4,040 & 548 & 4,588 \\
\hline 433 & Czech Republic & 8 & 891,000 & 20 & 2,384 & 323 & 2,708 \\
\hline 434 & Sweden & 10 & 887,000 & 13 & 2,374 & 322 & 2,696 \\
\hline 435 & Portugal & 9 & 851,000 & 29 & 2,276 & 309 & 2,584 \\
\hline 436 & Austria & 12 & 846,000 & 5 & 2,264 & 307 & 2,571 \\
\hline 437 & Netherlands & 4 & 722,000 & 1 & 1,930 & 262 & 2,192 \\
\hline 438 & Hungary & 6 & 698,000 & 27 & 1,867 & 253 & 2,120 \\
\hline 439 & Belgium & 6 & 668,000 & 16 & 1,787 & 242 & 2,029 \\
\hline 440 & Greece & 6 & 664,000 & 8 & 1,776 & 241 & 2,017 \\
\hline 441 & Finland & 11 & 618,000 & 17 & 1,654 & 224 & 1,879 \\
\hline 442 & Irish Republic & 13 & 561,000 & 35 & 1,500 & 203 & 1,703 \\
\hline 443 & Denmark & 11 & 527,000 & 9 & 1,411 & 191 & 1,602 \\
\hline 444 & Switzerland & 7 & 525,000 & 2 & 1,405 & 191 & 1,596 \\
\hline 445 & Norway & 11 & 520,000 & 18 & 1,391 & 189 & 1,580 \\
\hline 446 & Bulgaria & 7 & 511,000 & 43 & 1,368 & 186 & 1,553 \\
\hline 447 & Slovakia & 7 & 408,000 & 36 & 1,091 & 148 & 1,239 \\
\hline 448 & Lithuania & 11 & 345,000 & 26 & 922 & 125 & 1,047 \\
\hline 449 & Slovenia & 13 & 270,000 & 45 & 723 & 98 & 821 \\
\hline 450 & Latvia & 9 & 191,000 & 29 & 511 & 69 & 580 \\
\hline 451 & Estonia & 11 & 128,000 & 18 & 342 & 46 & 388 \\
\hline 452 & Luxembourg & 9 & 42,000 & 1 & 113 & 15 & 129 \\
\hline 453 & Iceland & 7 & 18,000 & 9 & 47 & 6 & 54 \\
\hline 454 & Malta & 2 & 7,000 & 1 & 19 & 3 & 22 \\
\hline 455 & & & & & & & \\
\hline 456 & Total & - & $35,234,000$ & - & 94,260 & 12,785 & 107,045 \\
\hline
\end{tabular}

459 Table 4: Population density-based screened market potential for small modular wastewater management systems in Europe and current population

460 percentages without central treatment (Eurostat, 2017). 


\section{Accepted in Land Use Policy}

Figure $4 a$ shows the geographical distribution of the three density classes, and Figure $4 \mathrm{~b}$ shows the result of a standard parameter model. On average, the highest market potentials are found in rural areas and the lowest ones in urban areas (with peri-urban areas in-between) (cf. box plots in Figure 3). Furthermore, little variation is found for high-density values, whereas large differences are seen in the market potentials for raster cells with low densities.

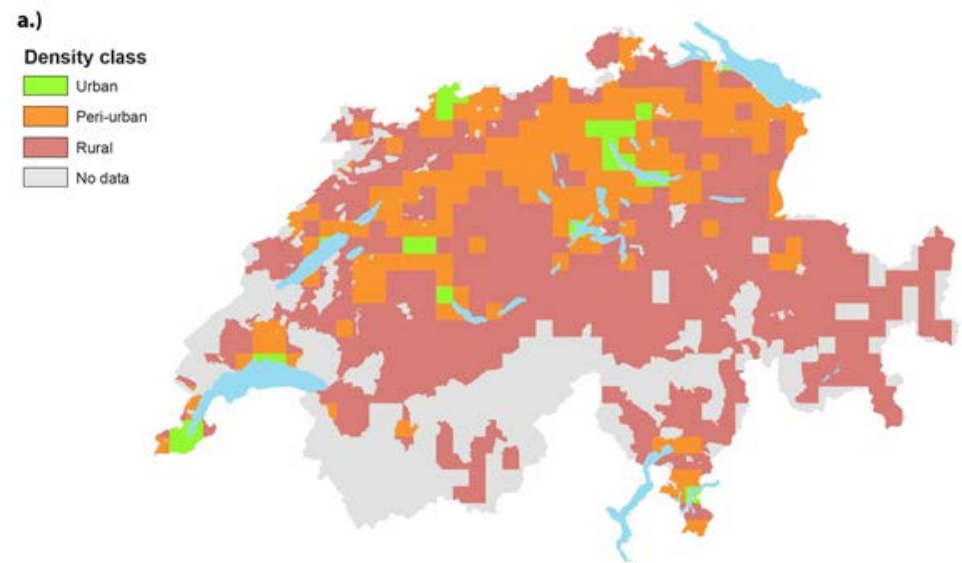

b.)

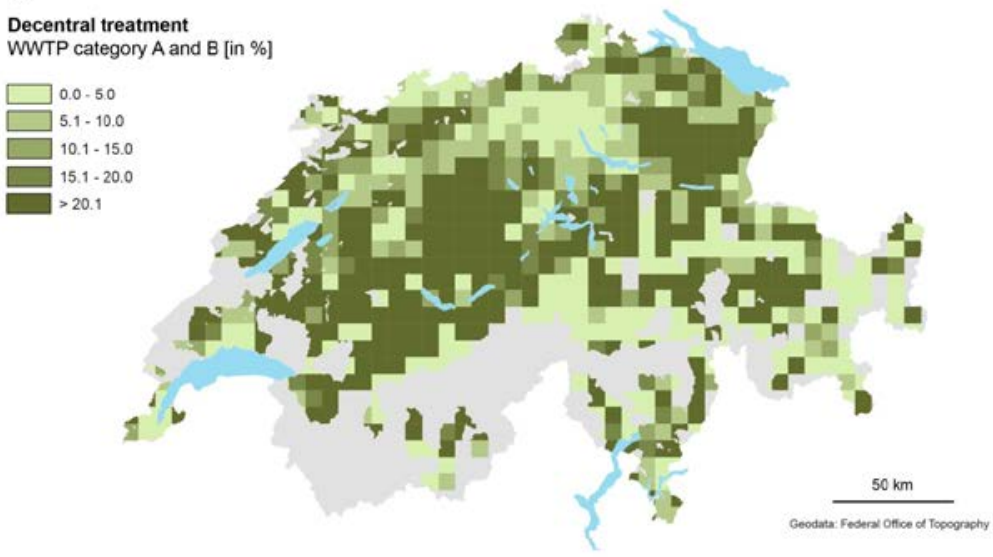

Figure 4: a) Geospatial distribution of the three identified density classes (b) and raster-based results for the market potential of decentralised wastewater treatment in Switzerland (geodata source: Swisstopo, 2015).

A comparison between the catchment-based (a) and raster-based (b) approaches in Figure 5 shows that even though the aggregated results change because of the different choice of geographical unit of analysis, the differences do not change the overall pattern. The choice of 

results of the present analysis.

a.)

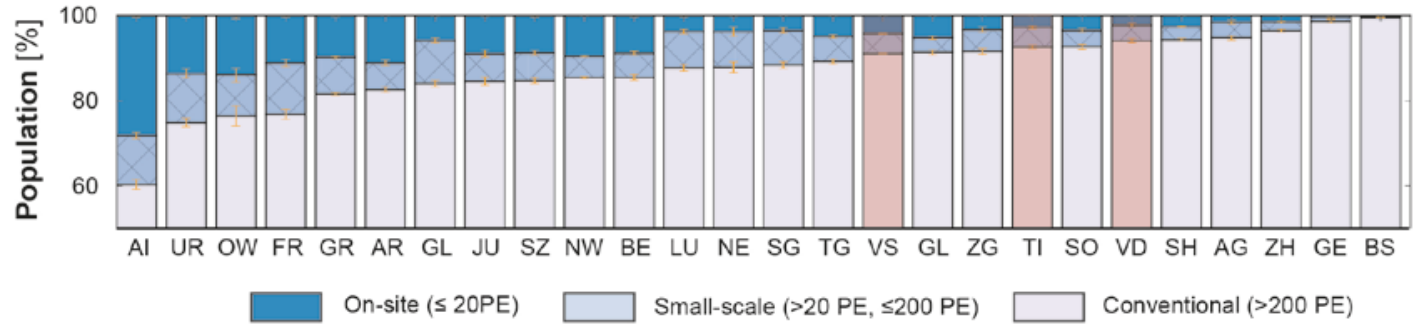

b.)

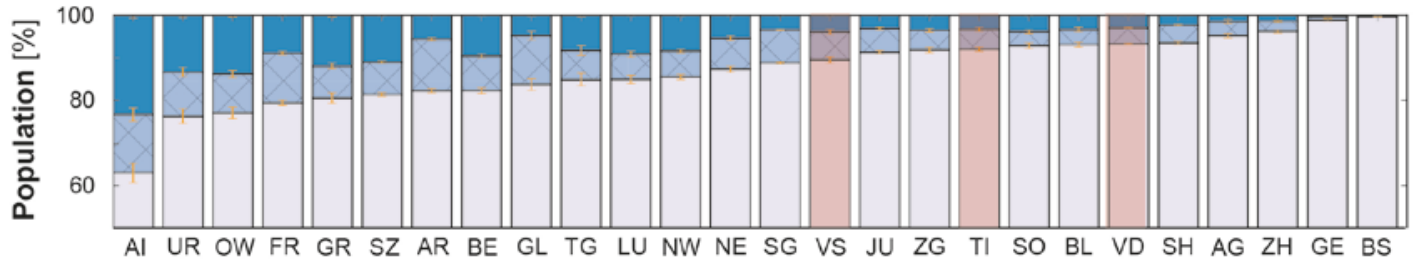

Swiss cantons

477

Figure 5: WWTP categories aggregated at a cantonal level on the basis of a) WWTP catchment calculations, and b) raster-based calculations. According to Figure 1, the results for VS, VD and $\mathrm{TI}$ (indicated in red) are not representative because of poor data availability (error bars represent \pm one standard deviation).

\section{Identifying density measures as proxy indicators}

Transferring the methodology from the Swiss case study to other countries is challenging for reasons of data availability and computation time. Therefore, we propose an alternative approach, namely identifying potential proxy indicators for which data are widely available and which seem likely to provide a reasonable estimation of the more detailed calculations that we ran for the Swiss case. Density measures are obvious candidates for this purpose. We will first review the state of discussion of density measures as a means of infrastructure planning before going on to analyse three density indicators as correlates for our calculated market potentials.

\subsection{Density measures in UWM}

It has hitherto been suggested in the literature that population density can act as a generic indicator for infrastructure planning because it often 'underlies the economic rationality when 
planning the provision of basic public infrastructure' (Prieto, Zofío and Álvarez, 2014). Overall, however, only a few studies support the argument that population density can indeed be used to identify the market potentials of centralised or small modular technologies. It would be far beyond the scope of the present paper to review the extensive literature on population density measures in infrastructure planning and we will therefore focus on how these arguments have been applied to the field of UWM.

It is generally true for different infrastructures that 'keeping all other factors constant, reduced urban density can be assumed to cause higher per-capita infrastructure costs' (Siedentop and Fina, 2010). Álvarez et al. (2014) analyse the efficiency of public infrastructures with respect to optimal population densities and differentiate between network-based and other types of infrastructures because not all infrastructures are 'equally affected by the spatial distribution patterns of population and dwellings.' Hence, the economic efficiency of network-based infrastructures in particularly is closely linked to population density (McKinsey, 2014; Prieto, Zofío and Álvarez, 2014). Specifically with respect to wastewater management, there is general agreement about various cost effects based on (population)-densities: the most common argument is that capital costs decrease if more people are connected to a system within a catchment because of economies of scale in wastewater treatment and shorter per capita sewer transportation distances (inter alia Adams et al., 1972; O'Flaherty, 2005). However, the cost effects are not limited to capital but include operation costs. In a similar way, economies of density, for example, can be found for the operation of both centralised and decentralised wastewater management systems (Eggimann, Truffer and Maurer, 2016a; Fontecha et al., 2016). Because of these various cost effects, population density has been suggested as a proxy in some studies, as it can act as an indicator for the optimal share of central and decentralised technologies in a region (Ho, 2005; Weber, Cornel and Wagner, 2007; Massoud, Tarhini and Nasr, 2009). Massoud, Tarhini and Nasr (2009), for example, write that in order to choose appropriate sanitation technologies 'population density and location and the efficiency of the technology as compared to its cost should be considered' (see also Cashman et al., 2018). Similarly, Van Afferden et al. (2010) state that the low population densities found in remote rural areas make the implementation of centralised treatment difficult. Urban form which is used to 
521

522

523

524

525

526

527

528

529

530

531

532

533

534

535

536

537

538

539

540

541

542

543

544

545

546

estimate wastewater management costs is closely related to population density (ECOPLAN 2000). Spirandelli (2015) also finds different patterns of wastewater infrastructures depending on the urban gradient. Finally, Bieker et al. (2010) write that 'wherever certain thresholds of population density are exceeded,' semi-centralised approaches offer new flexible solutions, and Kerstens et al. (2015) confirm that wastewater systems can be planned on a national scale on the basis of key parameters such as urban/rural features. However, putting forward the concept of population density as a measure for estimating centralised and decentralised treatment bears the risk of conveying the idea that high population density values are not suitable for decentralised treatment. Numerous examples however show that increasingly in highly urban settings new opportunities arise for decentralised treatment, such as e.g. in high-rises in cities. In summary, literature shows that population density clearly is an important and suitable indicator for drawing conclusion on the degree of centralisation in wastewater treatment. It is however also obvious, that population density is not able to capture all processing which lead to more centralised or decentralised infrastructures. Finally, even though population density is commonly put forward in theory, its quantification often lacks detail and little in the way of concrete analysis is available.

\subsection{Correlating density measures and market potentials}

Even though very different density measures are proposed in the literature, they are all based on the characteristics of buildings, settlement or zonal areas or catchments (inter alia Forsyth, 2003). We select three widely used indicators which are easy to calculate from a data availability point of view in the UWM, namely population (Equation 3), settlement (Equation 4) and building density (Equation 5) to correlate the calculated potential with the different WWTP categories defined in Table 1:

$$
\text { settlement density }=\frac{\text { catchment population }}{\text { settlement area }} * \frac{[\mathrm{PE}]}{\left[\mathrm{km}^{2}\right]}
$$


547

548

549

550

551

552

553

554

555

556

557

558

559

560

561

562

563

564

565

In the Swiss case study context, the population density within WWTP catchments varies considerably, with generally lower values for smaller catchments and higher values for larger ones of almost $100 \%$ connection rate, indicating that full connection might not be equally efficient for all catchments (Figure 6).

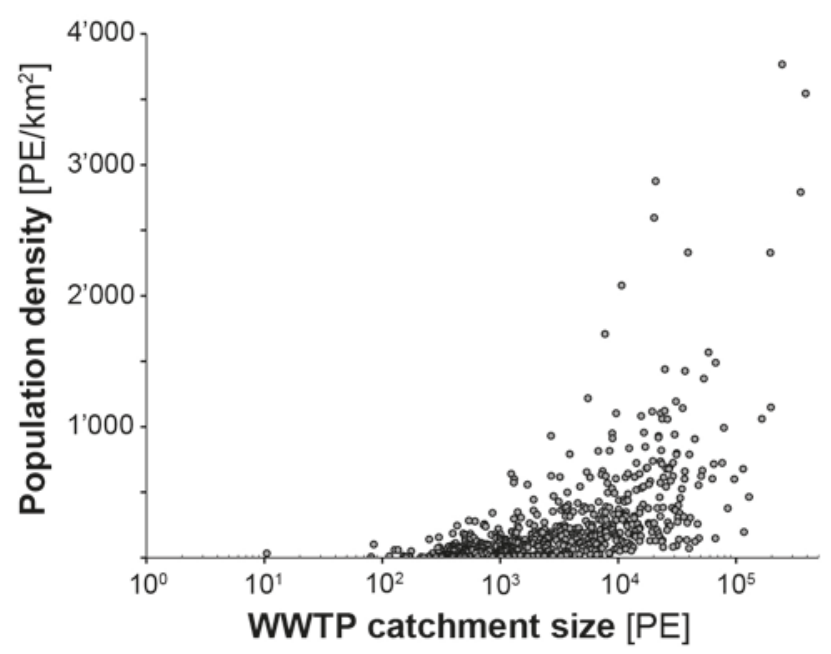

Figure 6: Population density of Swiss WWTP catchments $(n=607)$.

Figure 7 compares different density measures with the calculated market potential for decentralised wastewater treatment: with increasing population density, the market potential for decentralised systems decreases exponentially, resulting in low market potentials for higher densities and high potentials for low-density values (Figure 7a). However, high scattering can be observed, especially for lower densities. A possible explanation for the large differences for small densities is that our model-based approach considers actual network sewer layouts and topography. The overall fitting accuracy is considerably improved if we assume a piecewise linear approximation within the defined density classes, deduced from natural breaks in the data which can be identified at around 200 and $1000 \mathrm{PE} / \mathrm{km}^{2}$ (Figure 3). For the settlement density (Figure 7b), higher values are generally observed because wider areas not belonging to the settlements are excluded. However, the density differences are much smaller and no trend can 
566

567

568

569

570

a.)

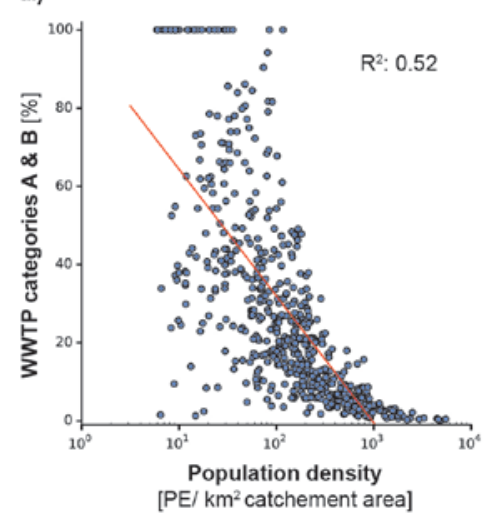
density measures.

be deduced from this measure. The correlation of the market potential for decentralised systems with the building density (Figure 7c) is weaker than with the regular population density, and no clear natural breaks can be observed in the data. We therefore state that population density is the most valuable proxy for approximating cost-efficient treatment scales from the selected
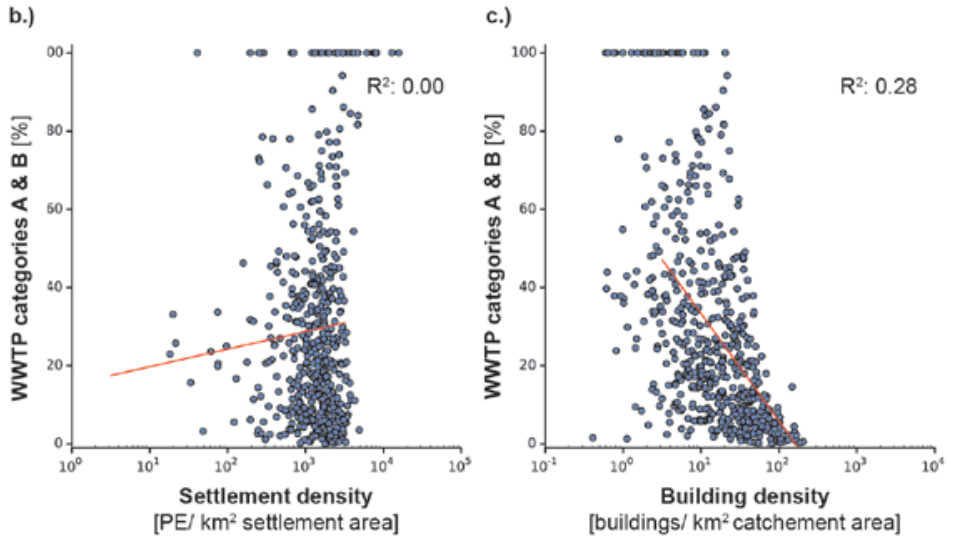

571

572

Figure 7: Comparison of density measures with the calculated market potential for decentralised

573 wastewater treatment for all raster cells (cf. Table 1).

574

Density measures imply several potential biases that should be considered when using them as

575 a proxy. Because population density heavily relies on the territorial unit chosen for its calculation (Duncan, 1957) and obfuscates the distribution of population within the unit, this parameter reflects the spatial distribution of serviced households imperfectly. This can be clearly seen in Figure 7. Therefore, the extrapolation of the derived density values for Switzerland to other geographical contexts needs cautious reconsideration and alternative density measures may need to be developed that more effectively integrate influences of urban form, sprawl measures and topography. The present study is limited to a European screening. Screening of global market potentials would need further investigation of additional criteria such as climate, settlement structure and different regulations. Also, detailed on-the-ground analyses are necessary, particularly in low-density areas, because of the weak correlation between population density and market potentials for decentralised wastewater treatment. 


\section{Estimating market potentials on a continental scale}

587 Using population density measures as a proxy and taking current decentralised treatment as a starting point or entry market for small modular systems, enables us to extrapolate the market potential for small modular wastewater treatment systems at European level. European connection rates for centralised treatment vary between $0.6 \%$ (Kosovo) and 100\% (United Kingdom), mostly ranging between $50 \%$ and $80 \%$ (Eurostat, 2017). For decentralised systems, the reported data are less consistent or may even be unavailable. The percentage of the connected population ranges from 0\% (Greece, Malta, Albania, Kosovo) to 45\% in Croatia (Table 4). However, the level of treatment (primary to tertiary) is not specified. Besides the population served by decentralised and centralised treatment units, some people are without any controlled wastewater treatment. Apart from some South Eastern European countries, this population share is below $10 \%$. 91/271/EEC of 21 May 1991 and 98/15/EEC of 27 February 1998, which oblige member states to equip all communities of more than 2000PE with a sewer system and secondary treatment. Decentralised treatment is allowed if the cost of connection to a sewer system cannot be justified. Within this context, decentralised systems have been considered as a backward technology that needs upgrading in order to count as a viable alternative to centrally sewered systems. As the above data show, these policies have not yet been implemented in all member states, and some Eastern and Southern European countries in particular are lagging behind in this respect (European Commission, 2016).

\subsection{Applying the density-based screening method} Due to data and computing limitations, the detailed approach applied to the Swiss case study cannot be reproduced on a European level (cf. Section 2). The scope of the screening is limited to countries for which geospatial data on population density is available (Eurostat, 2011). To guarantee consistency with the Swiss analysis, a grid with the same cell size $(7.2 \times 7.2 \mathrm{~km})$ is placed across Europe. Population density is then re-sampled for each raster cell (cf. Equation 3) and classified as either urban, peri-urban or rural according to the density classes derived from 
614 the community-based classification of Switzerland (cf. Table 2). The relative population shares

615 living in rural, peri-urban or urban regions in each country can then be determined by summing

616 the population of the classified raster-cells and dividing by the total population of each country

617 (see Figure 8). Finally, the various national market potentials are interpolated by multiplying the

618 respective population in each density class by the corresponding calculated market potentials of

619 the Swiss case study (Section 2). The market potential is presented in terms of population

620 percentages and as PEs (Table 4 and Figure 8). For industry strategies, the number of small

621 modular plants that could be sold every year is of more immediate interest. This number is

622 calculated by assuming the same average distribution of treatment unit sizes as modelled for

623 the case of Switzerland. Fig. 3shows that from the total number of small modular plants $88 \%$ of

624 WWTPs fall into category A with a median treatment unit size of 10 PE and $12 \%$ fall into

625 category B with a median treatment unit size of 110 PE. The overall number of WWTPS of

626 category A and B would only lead to small differences in case country specific density classes

627 were used, as the percentage of category A and category B plants are similar for the density

628 classes (90.1\% for rural, 84.4\% for peri-urban, 88.8\% for urban). By assuming the same

629 average distribution for all European countries, we first calculate the absolute number of

630 treatment units with 10 PE and 110 PE respectively. In a second step we divide this absolute

631 number. by 15 years, as this is the average lifetime assumed in industry (Corominas et al.,

632 2013). Finally, all total annual numbers are summed to identify the market potential in terms of

633 treatment units per annum within Europe.

\section{$634 \quad 4.2 \quad$ Market potentials in Europe}

635 The screened market potentials for small modular systems lie between 2\% (Malta) and 13\% 636 (Irish Republic and Slovenia) of the total population (Figure 8). The summed total market 637 potential within the considered European countries amounts to approximately 35.2 million PE, 638 with $65 \%$ of this market potential being located in France (5.7 million PE), Germany (5.1 million 639 PE), Poland (3.9 million PE), Italy (3.4 million PE), the United Kingdom (2.7 million PE) and 640 Spain (2.1 million PE). 
641 In the case of Switzerland, the Swiss population increased by $\sim 5.7 \%$ or 428,000 inhabitants

642 between 2006 and 2011, leading to more areas with higher density values overall.

643 Consequently, the market potential for Switzerland is $2.7 \%$ lower than in Section 2 , mainly

644 because peri-urban areas were reclassified as urban areas. However, other factors may

645 contribute to this difference in addition to the changing distribution of population density values

646 in response to rapid demographic change. These may include statistical uncertainties,

647 particularly in the case of low-density values (Section 3). Nevertheless, this issue of future

648 demographic changes does not have trivial effects on the market potential, for instance because

649 high uncertainty or a decreasing population might favour more flexible decentralised systems.

650 The summed total number of small modular systems amounts to approximately 107,000

651 annually (Table 4). To specify entry markets, we relate the market potential to the current

652 situation (Figure 8).

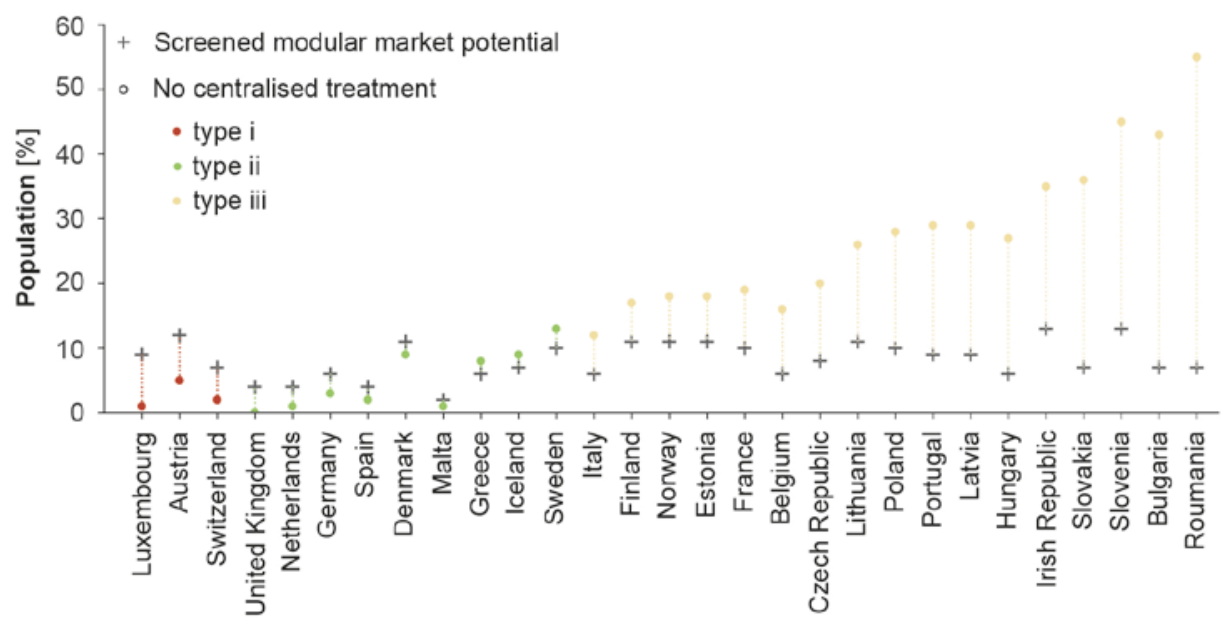

653

654 Figure 8: Comparison between extrapolated market potentials for small modular systems and population percentages with no central wastewater treatment. Three types of countries are defined depending on the $\pm 4 \%$ difference between the modelled and current situation. For data, see Table A1.

658 The comparison of the current situation with the extrapolated market potential allows three broad types of countries to be distinguished: 
i. Countries where the market potential is higher than the population share that is currently not connected to sewers. These have connected considerably more people (range of red, dotted line) to the centralised system than is economically justifiable (Luxembourg, Austria or Switzerland). If additional small modular units were to be introduced onto the market, this would involve disconnections from the centralised system. Resulting cost effects of disconnecting households from the existing network by transitioning towards more decentralised system configurations would need to be analysed in more detail (Eggimann, Truffer and Maurer, 2016b).

ii. Countries in which the difference between the market potential and the currently unconnected population share is within a certain limited range (here $\pm 4 \%$ ). For these countries, the extrapolated and current statuses of decentralised treatment either align or the population currently unconnected to any treatment could be serviced primarily by small modular treatment units (e.g. The United Kingdom, Netherlands, Germany or Spain).

iii. Countries in which the market potential is lower than the population unconnected to a centralised system (yellow, dotted line). This group can be divided into countries where a high share of the population unconnected to centralised treatment plants is served by decentralised units (e.g. France, Belgium, Irish Republic, Norway) and countries that need to increase their overall treatment infrastructure (e.g. Bulgaria or Romania).

Different planning agendas can be identified for the three types of countries on how to achieve more optimal degrees of centralisation and sufficient wastewater treatment according to European and national law. Countries of type (i) should reconsider mandatory connection rules, as hybrid systems are more appropriate in specific areas. Countries of type (ii) could essentially focus on the segment of small modular systems and support its technological upgrading with more sustainable alternatives. Necessary investments in the near future pose opportunities for a 'system hybridisation' (Marlow et al., 2013). Countries of type (iii) have to consider strengthening hybrid wastewater treatment. 


\section{Discussion}

688 We have identified a sizeable market for decentralised wastewater treatment systems in

689 Europe. We will now elaborate to what extent this implies an innovation opportunity for novel 690 and small modular concepts for handling urban waste water. The analysis identified a market 691 potential of about 100 '000 small modular treatment units (with a median of $10 \mathrm{PE}$ ) per annum 692 within Europe (see Table ). The market is concentrated in a few large countries, possibly with considerable internal regional diversity. Currently, most installed decentralised systems in

694 Europe are either sequencing batch reactors or biofilm systems, conventional activated sludge systems or treatment wetlands and only around $1 \%$ of systems are membrane-based (Schranner, 2014; Langergraber and Weissenbacher, 2017). In general, the application of these technologies suffers from a number of limitations, as they are typically owned and operated by non-professional organisations. Therefore, they are not very reliable in their operation, are costly to control and operate, especially if experts have to visit the plants on the ground, and are hard to regulate in conventional ways optimised for centralised systems (West et al., 2016). Also, there is little incentive for innovation and improvement in terms of future prospects: the market for decentralised plants is fairly splintered, utilities possess low innovation capabilities, regulations hinder improvements in treatment capacity, regulators tend not to promote the uptake of innovative options and professionals are generally risk-averse with respect to new approaches (Kiparsky et al., 2013, 2016). Consequently, decentralised systems have not been very well regarded by urban water professionals and regulators in the past, so connection to sewers is still seen as the preferred option. This in turn keeps the overall densities of decentralised units too low to develop cost-effective and reliable business models and regulatory approaches. Small modular infrastructures which can be mass-produced, automated and modularised, hold the promise that several of these limiting factors could be overcome and lead to dramatically different dynamics in terms of cost and performance. They may for instance improve treatment capacity compared to many of todays installed decentralised systems and result in overall system performance on a par with centralised concepts. As regards treatment system costs, 
modular infrastructures would build on prefabricated processing units that can permit very strong economies of scale in production (Hillenbrand, 2009; Dahlgren et al., 2013). New business models and regulatory approaches based on novel communication and sensor technologies potentially enable systems to be supervised without involving individual houseowners, and thus improve the reliability of modular systems (Eggimann et al., 2017). Implementing contracting concepts with centralised operation would additionally have the advantage that contractors could order and install larger numbers of identical systems, which would help to lower costs and help their diffusion (Hiessl et al., 2010). On a system configuration level, this would open up a number of new degrees of freedom to reorganise the urban water sector, most importantly enabling a different approach to storm water management, water reuse and resilience related to natural disasters, decrease the net use of water in households and reduce overall costs for communities and households (US-NRC, 2012; Cornejo, Zhang and Mihelcic, 2016; Mangone, 2016; Naik and Stenstrom, 2016; Vázquez-Rowe, Kahhat and Lorenzo-Toja, 2017). The question about public or private operation however needs to be discussed elsewhere (Lieberherr and Truffer, 2015; Eggimann, Truffer and Maurer, 2016b).

All told, we posit that if a dedicated innovation effort were to be undertaken to develop modular systems, the sustainability record of the sector as a whole could improve (Larsen et al. 2016). These developments could eventually lead to market shares of small modular systems far above those that we have identified for current decentralised systems. This analysis is however not a forecast on what the future will hold in terms of deployed technologies as the market will depend on vast array of socio-technical developments and is context specific (taxation, regulatory framework etc.). It therefore only serves as an indicator for the geographies where these new system concepts could be developed and implemented. In terms of industry strategies, our extrapolation to the overall European market of about 100'000 small modular systems per annum would permit considerable economies of scale and learning. Furthermore, the market is concentrated in a few major countries, which would enable robust entry and early follower markets to be specified. These offer substantial prospects for Europe and even more so in other OECD countries that increasingly suffer from water shortages due to extended droughts, or where urban water systems are impacted by heavy storm events (Frei et al., 2006). 
Also, small modular infrastructures would provide an interesting option for rapidly growing cities in emerging economies, where the building of centralised water infrastructure is difficult to achieve and high growth rates call for increased flexibility, which is much better provided by small modular systems (Maurer, 2009). Furthermore, standardised and mass-produced small modular systems would most likely lead to improved performance where infrastructures are poor, as is often the case in development contexts. Finally, the standardisation and mass production will lead to a substantial cost reduction and promise to reduce other obstacles which are preventing the technology to diffuse and find wide practical application (Wilderer and Schreff, 2000; Hiessl et al., 2010).

Small modular infrastructures are therefore likely to play an important role in tackling future water-related problems due to global environmental change. However, incentives for embarking on these types of systemic innovation processes depend on initiatives by policy-makers, utilities and local governments to implement these technologies in an innovative way (Hoogma, 2002). Whether these opportunities will be grasped depends on political will and the further development of impacts due to global environmental change in the realm of water. This situation resembles earlier large policy programs that have led to fundamental changes in major industry sectors in the recent past (Foray, Mowery and Nelson, 2012; Larsen et al., 2016).

s.

\section{Conclusions}

Given the benefits that small modular infrastructure concepts promise, the dominant sewerbased approach to urban water management needs to be revisited in view of upcoming problems associated with global environmental change. Even though decentralised infrastructure concepts are suggested as emerging solutions to the water challenges of an urbanising world, so far only few studies have been available to assess the potential markets of novel small modular urban water systems. In most OECD countries, decentralised wastewater management has so far played a marginal role. Changing this state of affairs would necessitate 
running a large number of interrelated innovation processes. As a necessary precondition for this to happen, we have assessed the size of a potential market for small modular wastewater treatment technologies based on the cost characteristics of current technologies. An assessment based on a geospatial model for the example of Switzerland suggests market potentials of $\sim 10 \%$ of the overall population for decentralised wastewater treatment (<200 PE). This represents a potential market increase by a factor of almost twenty for these technologies. By correlating market potentials and density measures, we propose to use population density as a first approximation indicator to provide an orientation of transition potentials for small modular treatment systems and act as a guide to infrastructure investments. Density-based screening on a European scale reveals different realisable market potentials across different countries (about 100 '000 plants per year, cf. Table 4). Whereas eastern European countries in particular still need to realise their centralised and modular market potentials to provide sustainable sanitation to their whole populations, this analysis suggests that other countries such as Austria or Switzerland should transition towards more hybrid system configurations. Finally, tapping the considerable market potentials overall would require a major transition in the way the UWM sector is currently organised. This would additionally create major market opportunities for further developing and maturing small modular infrastructure concepts.

\section{Footnotes}

(1) A population equivalent is a unit used to compare pollution loads, including both industrial and residential organic loads. One PE corresponds to an organic load with a biochemical oxygen demand of $54 \mathrm{~g}$ of oxygen per day (OECD, 1997).

(2) The number of modelled category C WWTP $(2,823)$ by far exceeds the actual number of centralised WWTPs in Switzerland. On the one hand this can be explained by the heuristic used in the SNIP approach, which is optimised to identify households that could potentially be decoupled from the system. The merging of very large WWTP is not equally well implemented. On the other hand, there are mainly reasons other than costs as to why larger WWTP are encouraged by regulators in Swiss practice. 
797

798

799

800

801

802

803

804

805

806

807

808

(3) The optimisation is performed only within raster cells containing more than $300 \mathrm{PE}$ to allow for potential centralised treatment. The value of $300 \mathrm{PE}$ is taken as a selection criterion because in case fewer than 200PE are found within a raster cell, the algorithm would not detect centralised treatment as treatment systems would be classified as decentralised by definition (cf. Table 1).

(4) The difference in population percentages between the calculated optimal modular market potential and the current decentralised treatment (see Table 4) is 5\% for Switzerland (375,000 PE or 886 small modular systems per year), 7\% for Austria (493,500 PE, 1'499 small modular systems per year) and 8\% for Luxembourg (37'333 $\mathrm{PE}, 115$ small modular systems per year). The total potential maximum number of overestimated small modular treatment systems is roughly $2.5 \%$ (2'500 small modular systems per year or 900'000 PE) for the whole of Europe. 
Abd El Gawad, H. A. and Butter, J. H. C. (1995) 'Clustering of towns and villages for centralized wastewater treatment', in Water Science and Technology, pp. 85-95. doi: 10.1016/0273-1223(96)00121-7.

Adams, B. J., Dajani, J. S., Gemmell, R. S. and Adams B. J., Dajani J.S., G. R. S. (1972) 'On the centralization of wastewater treatment facilities', Water Resources Bulletin, 8(4), pp. 669-678. doi: 10.1111/j.1752-1688.1973.tb05845.x.

Adler, C. (2007) 'Market Potential of a Membrane Based Wastewater Treatment Plant for Decentralized Application in China An economic evaluation of a potential large-scale'.

Van Afferden, M., Cardona, J. A., Lee, M.-Y. M. Y., Subah, A. and Müller, R. A. (2015) 'A new approach to implementing decentralized wastewater treatment concepts', Water Science and Technology, 72(11), pp. 1923-1930. doi: 10.2166/wst.2015.393.

van Afferden, M., Cardona, J. A., Rahman, K. Z., Daoud, R., Headley, T., Kilani, Z., Subah, A. and Mueller, R. A. (2010) 'A step towards decentralized wastewater management in the Lower Jordan Rift Valley', Water Science \& Technology, 61(12), pp. 3117-3128. doi: 10.2166/wst.2010.234.

Alnouri, S. Y., Linke, P. and El-Halwagi, M. (2015) 'A synthesis approach for industrial city water reuse networks considering central and distributed treatment systems', Journal of Cleaner Production. Elsevier Ltd, 89, pp. 231-250. doi: 10.1016/j.jclepro.2014.11.005.

Álvarez, I. C., Prieto, Á. M. and Zofío, J. L. (2014) 'Cost efficiency, urban patterns and population density when providing public infrastructure: a stochastic Frontier Approach', European Planning Studies, 22(6), pp. 1235-1258. doi: 10.1080/09654313.2013.778957.

Ambros, R. (1996) 'Systemtheoretische Kritik am gegenwärtigen Lösungsweg. Ein postbürokratisches Gegenkonzept', Wiener Mitteilungen, Band 130, pp. 107-133.

Arora, M., Malano, H., Davidson, B., Nelson, R. and George, B. (2015) 'Interactions between centralized and decentralized water systems in urban context: A review', Wiley Interdisciplinary Reviews: Water, 2(6), pp. 623-634. doi: 10.1002/wat2.1099.

Bach, P. M., Rauch, W., Mikkelsen, P. S., McCarthy, D. T. and Deletic, A. (2014) 'A critical review of integrated urban water modelling - Urban drainage and beyond', Environmental Modelling \& Software. Elsevier Ltd, 54, pp. 88-107. doi: 10.1016/j.envsoft.2013.12.018.

BAFU (2016) Indicator Connection rate and performance level of wastewater treatment plants. Available at: http://www.bafu.admin.ch/umwelt/indikatoren/08605/08610/index.html?lang=de (Accessed: 9 August 2016).

Bahri, A. (2012) Integrated Urban Water Management, TEC Background Papers No.16. Stockholm: Global Water Partnership Technical Committee (TEC). 
850

851

852

853

854

855

856

857

858

859

860

861

862

863

864

865

866

867

868

869

870

871

872

873

874

875

876

877

878

879

880

881

882

883

884

885

886

887

888

889

890

891

892

Baron, S., Kaufmann Alves, I., Schmitt, T. G., Schöffel, S. and Schwank, J. (2015) 'Cross-sectoral optimization and visualization of transformation processes in urban water infrastructures in rural areas', Water Science and Technology, 72(10), pp. 1730-1738. doi: 10.2166/wst.2015.378.

Bieker, S., Cornel, P. and Wagner, M. (2010) 'Semicentralised supply and treatment systems: Integrated infrastructure solutions for fast growing urban areas', Water Science and Technology, 61(11), pp. 2905-2913. doi: 10.2166/wst.2010.189.

Braga, B., Chartres, C., Cosgrove, W. J., da Cunha, L. V., Gleick, P. H., Kabat, P., Kadi, M. A., Loucks, D. P., Lundqvist, J., Narain, S. and Xia, J. (2014) Water and the future of humanity: Revisiting water security. Springer. doi: 10.1007/978-3-31901457-9.

Cashman, S., (Cissy) Ma, X., Mosley, J., Garland, J., Crone, B. and Xue, X. (2018) 'Energy and greenhouse gas life cycle assessment and cost analysis of aerobic and anaerobic membrane bioreactor systems: Influence of scale, population density, climate, and methane recovery', Bioresource Technology. doi: 10.1016/j.biortech.2018.01.060.

Converse, O. A. (1972) 'Optimum treatment number plants and location of', Water Pollution Control Federation, 44(8), pp. 1629-1636.

Cornejo, P. K., Zhang, Q. and Mihelcic, J. R. (2016) 'How does scale of implementation impact the environmental sustainability of wastewater treatment integrated with resource recovery?', Environmental Science \& Technology, 50(13), p. acs.est.5b05055. doi: 10.1021/acs.est.5b05055.

Corominas, L., Foley, J., Guest, J. S., Hospido, A., Larsen, H. F., Morera, S. and Shaw, A. (2013) 'Life cycle assessment applied to wastewater treatment: State of the art', Water Research. Elsevier Ltd, 47(15), pp. 5480-5492. doi: 10.1016/j.watres.2013.06.049.

Dahlgren, E., Göçmen, C., Lackner, K. and van Ryzin, G. (2013) 'Small Modular Infrastructure', The Engineering Economist, 58(4), pp. 231-264. doi: 10.1080/0013791X.2013.825038.

Daigger, G. T. (2007) 'Wastewater Management in the 21st Century', Journal of Environmental Engineering, 133(7), pp. 671-680. doi: 10.1061/(ASCE)07339372(2007)133:7(671).

Deininger, R. A. and Su, S. Y. (1973) 'Modelling regional waste water treatment systems', Water Research, 7(4), pp. 633-646. doi: 10.1016/0043-1354(73)90063-8.

Downing, P. B. (1969) The Economics of Urban Sewage Disposal. New York: Praeger.

Duncan, O. D. (1957) 'The Measurement of Population Distribution', Population Studies, 11(1), pp. 27-45. doi: 10.2307/2172508.

Eawag (2014) 'Reworked on the basis of Maurer M. and Herlyn A. (2007) Zustand, Kosten und Investitionsbedarf der schweizerischen Abwasserentsorgung. Eawag/Bafu.'

ECOPLAN (2000) Siedlungsentwicklung und Infrastrukturkosten. Bern, Switzerland. Available at: http://www.ecoplan.ch/download/sik_sb_de.pdf. 
Eggimann, S., Mutzner, L., Wani, O., Schneider, M. Y., Spuhler, D., Moy De Vitry, M., Beutler, P. and Maurer, M. (2017) 'The Potential of Knowing More: A Review of DataDriven Urban Water Management', Environmental Science and Technology, 51(5), pp. 2538-2553. doi: 10.1021/acs.est.6b04267.

Eggimann, S., Truffer, B. and Maurer, M. (2015) 'To connect or not to connect? Modelling the optimal degree of centralisation for wastewater infrastructures', Water Research. Elsevier Ltd, 84, pp. 218-231. doi: 10.1016/j.watres.2015.07.004.

Eggimann, S., Truffer, B. and Maurer, M. (2016a) 'Economies of density for on-site waste water treatment', Water Research. Elsevier Ltd, 101, pp. 476-489. doi: 10.1016/j.watres.2016.06.011.

Eggimann, S., Truffer, B. and Maurer, M. (2016b) 'The cost of hybrid waste water systems: A systematic framework for specifying minimum cost-connection rates', Water Research. Elsevier Ltd, 103, pp. 472-484. doi: 10.1016/j.watres.2016.07.062.

European Commission (2016) 'Report from the commission to the european parliment, the council, the european economic and social committe and the committee of the regions. Eighth Report on the Implementation Status and the Programmes for Implementation (as required by Article 17) of', 105, pp. 1-17. doi: 10.1017/CBO9781107415324.004.

Eurostat (2011) 'GEOSTAT $1 \mathrm{~km} 2$ population grid (GEOSTAT_grid_POP_1K_2011_V2)'. Available at: http://ec.europa.eu/eurostat/web/gisco/geodata/reference-data/populationdistribution-demography (Accessed: 25 May 2017).

Eurostat (2017) Population connected to urban wastewater collecting and treatment systems, by treatment level. Available at:

http://ec.europa.eu/eurostat/tgm/refreshTableAction.do?tab=table\&plugin=1\&pcode=t en00020\&language $=e n$ (Accessed: 19 May 2017).

Fagan, J. E., Reuter, M. A. and Langford, K. J. (2010) 'Dynamic performance metrics to assess sustainability and cost effectiveness of integrated urban water systems', Resources, Conservation and Recycling. Elsevier B.V., 54(10), pp. 719-736. doi: 10.1016/j.resconrec.2009.12.002.

Fane, A. G. and Fane, S. A. (2005) 'The role of membrane technology in sustainable decentralized wastewater systems.', Water science and technology: a journal of the International Association on Water Pollution Research, 51(10), pp. 317-325.

Federal Office for Spatial Development (2005) Im Rahmen des Monitorings ländlicher Raum verwendete Raumtypologien. Bern, Switzerland.

Federal Office of Topography swisstopo (ed.) (2006) swissBUILDINGS3D 1.0. Wabern, Switzerland.

Federal Statistical Office (ed.) (2006) Federal Register for Buildings and Dwellings. Neuchâtel, Switzerland.

Federal Statistical Office (BFS) (ed.) (2006) Bilanz der ständigen Wohnbevölkerung nach Demographische Komponente, Kanton, Bezirk, Gemeinde (......), Staatsangehörigkeit, Geschlecht und Jahr. Neuchâtel, Switzerland.

Fletcher, T. D., Shuster, W., Hunt, W. F., Ashley, R., Butler, D., Arthur, S., Trowsdale, 
S., Barraud, S., Semadeni-Davies, A., Bertrand-Krajewski, J.-L., Mikkelsen, P. S., Rivard, G., Uhl, M., Dagenais, D. and Viklander, M. (2015) 'SUDS, LID, BMPs, WSUD and more - The evolution and application of terminology surrounding urban drainage', Urban Water Journal, 12(7), pp. 525-542. doi: 10.1080/1573062X.2014.916314.

Fontecha, J. E., Akhavan-Tabatabaei, R., Duque, D., Medaglia, A. L., Torres, M. N. and Rodríguez, J. P. (2016) 'On the preventive management of sediment-related sewer blockages: A combined maintenance and routing optimization approach', Water Science and Technology, 75(1). doi: 10.2166/wst.2016.160.

Foray, D., Mowery, D. C. and Nelson, R. R. (2012) 'Public R\&D and social challenges: What lessons from mission R\&D programs?', Research Policy, 41(10), pp. 1697-1702. doi: 10.1016/j.respol.2012.07.011.

Forsyth, A. (2003) 'Measuring Density: Working Definitions for Residential Density and Building Intensity', Design Center for American Urban Landscape. Minneapolis, MN, USA, 8(8), pp. 2-8.

Frei, C., Schöll, R., Fukutome, S., Schmidli, J. and Vidale, P. L. (2006) 'Future change of precipitation extremes in Europe: Intercomparison of scenarios from regional climate models', Journal of Geophysical Research Atmospheres, 111(6). doi: 10.1029/2005JD005965.

Friedler, E. and Hadari, M. (2006) 'Economic feasibility of on-site greywater reuse in multi-storey buildings', Desalination, 190(1-3), pp. 221-234. doi: 10.1016/j.desal.2005.10.007.

Fuenfschilling, L. and Binz, C. (2018) 'Global socio-technical regimes', Research Policy. Elsevier, 47(4), pp. 735-749. doi: 10.1016/j.respol.2018.02.003.

Fuenfschilling, L. and Truffer, B. (2014) 'The structuration of socio-technical regimes-Conceptual foundations from institutional theory', Research Policy. Elsevier B.V., 43(4), pp. 772-791. doi: 10.1016/j.respol.2013.10.010.

Gaulke, L. S. (2006) 'On-site wastewater treatment and reuses in Japan', Proceedings of the ICE - Water Management, 159(2), pp. 103-109. doi: 10.1680/wama.2006.159.2.103.

Gawel, E. (eds) (2015) Die Governance der Wasserinfrastruktur (Band I \& II). Rahmenbedingungen, Herausforderungen und Optionen. Berlin, Germany: Duncker \& Humblot.

Geels, F. W. (2006) 'The hygienic transition from cesspools to sewer systems (18401930): The dynamics of regime transformation', Research Policy, 35(7), pp. 10691082. doi: 10.1016/j.respol.2006.06.001.

Grant, S. B., Saphores, J.-D., Feldman, D. L., Hamilton, A. J., Fletcher, T. D., Cook, P. L. M., Stewardson, M., Sanders, B. F., Levin, L. a., Ambrose, R. F., Deletic, A., Brown, R., Jiang, S. C., Rosso, D., Cooper, W. J. and Marusic, I. (2012) 'Taking the "Waste" Out of "Wastewater" for Human Water Security and Ecosystem Sustainability', Science, 337(6095), pp. 681-686. doi: 10.1126/science.1216852.

Guo, T. and Englehardt, J. (2015) 'Principles for scaling of distributed direct potable water reuse systems: A modeling study', Water Research. Elsevier Ltd, 75, pp. 146- 
163. doi: 10.1016/j.watres.2015.02.033.

Guo, T., Englehardt, J. D. and Fallon, H. J. (2016) 'Modeling the Economic Feasibility of Large-Scale Net-Zero Water Management: A Case Study', Water Environment Research, 88(9), pp. 811-823. doi: 10.2175/106143016X14609975747487. Hall, J. W., Tran, M., Hickford, A. J. and Nicholls, R. J. (2016) The future of national infrastructure : a system-of-systems approach. Edited by J. W. Hall, M. Tran, A. J. Hickford, and R. J. Nicholls. Cambridge: Cambridge University Press. doi: 10.1017/CBO9781107588745.

Hering, J. G., Waite, T. D., Luthy, R. G., Drewes, J. E. and Sedlak, D. L. (2013) 'A changing framework for urban water systems', Environmental Science and Technology, 47(19), pp. 10721-10726. doi: 10.1021/es4007096.

Hiessl, H., Toussaint, D., Becker, M., Geisler, S., Hetschel, M., Werbeck, N., Kersting, M., Schürmann, B., Dyrbusch, A., Sanden, J. and Unrast, L. (2010) AKWA Dahler Feld: Contracting im Bereich der Wasserwirtschaft. ISI-Schrif. Edited by Frauenhofer-Institut für System- und Innovationsforschung ISI. Stuttgart: Fraunhofer Verlag.

Hillenbrand, T.; Hiessel, H. (2016) Pilotprojekt »DEUS 21 «: Nachhaltige urbane Wasserinfrastruktursysteme. Edited by T. Kluge. Münche: oekom verlag.

Hillenbrand, T. (2009) Analyse und Bewertung neuer urbaner Wasserinfrastruktursysteme, Schriftenreieh SWW - Band 134. Karlsruhe, Germany.

Hillenbrand, T., Hiessl, H., Klug, S., Freiherr von Lüninck, B., Niederste-Hollenberg, J., Sartorius, C. and Walz, R. (2013) 'Herausforderungen einer nachhaltigen Wasserwirtschaft', (158), p. 212. Available at: http://www.tab-beimbundestag.de/de/pdf/publikationen/berichte/TAB-Arbeitsbericht-ab158.pdf.

Ho, G. (2005) 'Technology for sustainability: The role of onsite, small and community scale technology', Water Science and Technology, 51(10), pp. 15-20.

Hoogma, R. (2002) Exploiting technological niches: strategies for experimental introduction of electric vehicles. Twente University, Enschede.

Huskova, I., Matrosov, E. S., Harou, J. J., Kasprzyk, J. R. and Lambert, C. (2016) 'Screening robust water infrastructure investments and their trade-offs under global change: A London example', Global Environmental Change. Elsevier Ltd, 41, pp. 216-227. doi: 10.1016/j.gloenvcha.2016.10.007.

Hutton, G. and Haller, L. (2004) 'Evaluation of the Costs and Benefits of Water and Sanitation Improvements at the Global Level', World Health Organization, pp. 1-87. doi: 10.2166/wh.2007.008.

Kavvada, O., Horvath, A., Stokes-Draut, J. R., Hendrickson, T. P., Eisenstein, W. I. and Nelson, K. L. (2016) 'Assessing Location and Scale of Urban Non-Potable Water Reuse Systems for Life-Cycle Energy Consumption and Greenhouse Gas Emissions', Environmental Science \& Technology, 50(24), p. acs.est.6b02386. doi: 10.1021/acs.est.6b02386.

Kavvada, O., Nelson, K. . and Horvath, A. (2018) 'Spatial optimization for decentralized non-potable water reuse', Environmental Reserach Letters, 13(064001), pp. 1-12. 
Kerstens, S. M., Leusbrock, I. and Zeeman, G. (2015) 'Feasibility analysis of wastewater and solid waste systems for application in Indonesia', Science of The Total Environment. Elsevier B.V., 530-531, pp. 53-65. doi: 10.1016/j.scitotenv.2015.05.077.

Kiparsky, M., Sedlak, D. L., Thompson, B. H. and Truffer, B. (2013) 'The innovation deficit in urban water: the need for an integrated perspective on institutions, organizations, and technology', Environmental Engineering Science, 30(8), pp. 395408. doi: 10.1089/ees.2012.0427.

Kiparsky, M., Thompson, B. H., Binz, C., Sedlak, D. L., Tummers, L. and Truffer, B. (2016) 'Barriers to Innovation in Urban Wastewater Utilities: Attitudes of Managers in California', Environmental Management. Springer US, 57(6), pp. 1204-1216. doi: 10.1007/s00267-016-0685-3.

Langergraber, G. and Weissenbacher, N. (2017) 'Survey on number and size distribution of treatment wetlands in Austria', Water Science and Technology, 75(10), pp. 2309-2315. doi: 10.2166/wst.2017.112.

Larsen, T. a. and Gujer, W. (1997) 'The concept of sustainable urban water management', Water Science \& Technology, pp. 3-10. Available at: http://www.iwaponline.com/wst/03509/wst035090003.htm\%5Cnhttp://www.sciencedir ect.com/science/article/pii/S0273122397001790.

Larsen, T. A., Hoffmann, S., Lüthi, C., Truffer, B. and Maurer, M. (2016) 'Emerging solutions to the water challenges of an urbanizing world.', Science (New York, N.Y.), 352(6288), pp. 928-33. doi: 10.1126/science.aad8641.

Larsen, T. A., Udert, K. M. and Lienert, J. (2013) Source Separation and Decentralization for Wastewater Management, IWA Publishing. Edited by T. Larsen, K. Udert, and J. Lienert. London, U.K.: IWA Publishing. doi: 10.1017/CBO9781107415324.004.

Lee, E. J., Criddle, C. S., Bobel, P. and Freyberg, D. L. (2013) 'Assessing the scale of resource recovery for centralized and satellite wastewater treatment', Environmental Science and Technology, 47, pp. 10762-10770. doi: 10.1021/es401011k.

Li, L., Binz, C., Lu, Y., Truffer, B. and Shi, Y. (2013) 'Institutional trajectory for diffusing on-site wastewater treatment in urban China', Water Science and Technology, 68(5), pp. 1180-1187. doi: 10.2166/wst.2013.328.

Libralato, G., Volpi Ghirardini, A. and Avezzù, F. (2012) 'To centralise or to decentralise: An overview of the most recent trends in wastewater treatment management', Journal of Environmental Management. Elsevier Ltd, 94(1), pp. 61-68. doi: 10.1016/j.jenvman.2011.07.010.

Lieberherr, E. and Truffer, B. (2015) 'The impact of privatization on sustainability transitions: A comparative analysis of dynamic capabilities in three water utilities', Environmental Innovation and Societal Transitions. Elsevier B.V., 15, pp. 101-122. doi: 10.1016/j.eist.2013.12.002.

Lienhoop, N., Al-Karablieh, E. K., Salman, A. Z. and Cardona, J. A. (2014) 'Environmental cost-benefit analysis of decentralised wastewater treatment and reuse: a case study of rural Jordan', Water Policy, 16(2), pp. 323-339. doi: 


\subsection{6/wp.2013.026.}

Lüthi, C., Panesar, A., Schütze, T., Norström, A., Mcconville, J., Parkinson, J., Saywell, D. and Ingle, R. (2011) Sustainable sanitation in cities. A freamwork for action. First Edit. Rijswijk, The Netherlands: Papiroz Publishing House.

Lwin, K. and Murayama, Y. (2009) 'A GIS Approach to Estimation of Building Population for Micro-spatial Analysis', Transactions in GIS, 13(4), pp. 401-414. doi: 10.1111/j.1467-9671.2009.01171.x.

Makropoulos, C. K. and Butler, D. (2010) Distributed water infrastructure for sustainable communities, Water Resources Management. doi: 10.1007/s11269-0109580-5.

Mangone, G. (2016) 'Constructing hybrid infrastructure: Exploring the potential ecological, social, and economic benefits of integrating municipal infrastructure into constructed environments', Cities. Elsevier B.V., 55, pp. 165-179. doi: 10.1016/j.cities.2016.04.004.

Markard, J., Raven, R. and Truffer, B. (2012) 'Sustainability transitions: An emerging field of research and its prospects', Research Policy. Elsevier B.V., 41(6), pp. 955967. doi: 10.1016/j.respol.2012.02.013.

Marlow, D. R., Moglia, M., Cook, S. and Beale, D. J. (2013) 'Towards sustainable urban water management: A critical reassessment.', Water research. Elsevier Ltd, 47(20), pp. 7150-7161. doi: 10.1016/j.watres.2013.07.046.

Martínez Arranz, A. (2017) 'Lessons from the past for sustainability transitions? A meta-analysis of socio-technical studies', Global Environmental Change. Elsevier Ltd, 44, pp. 125-143. doi: 10.1016/j.gloenvcha.2017.03.007.

Massoud, M. A., Tarhini, A. and Nasr, J. A. (2009) 'Decentralized approaches to wastewater treatment and management: applicability in developing countries.', Journal of Environmental Management. Elsevier Ltd, 90(1), pp. 652-659. doi: 10.1016/j.jenvman.2008.07.001.

Maurer, M. (2009) 'Specific net present value: An improved method for assessing modularisation costs in water services with growing demand', Water Research, 43(8), pp. 2121-2130. doi: 10.1016/j.watres.2009.02.008.

Maurer, M., Scheidegger, A. and Herlyn, A. (2013) 'Quantifying costs and lengths of urban drainage systems with a simple static sewer infrastructure model', Urban Water Journal, 10(4), pp. 268-280. doi: 10.1080/1573062X.2012.731072.

Mayer, J. N., Philipps, D. S., Hussein, N. S., Schlegl, T. and Senkpiel, C. (2015) Current and Future Cost of Photovoltaics Current and Future Cost of Photovoltaics. Berlin, Germany.

Mcdonald, A. and Schrattenholzer, L. (2002) 'Learning Curves and Technology Assessment', Reprinted from International Journal of Technology Management, 23(78), pp. 718-745. Available at: http://pure.iiasa.ac.at/id/eprint/6787/1/RR-03002.pdf.

McDonald, R. I., Weber, K., Padowski, J., Flörke, M., Schneider, C., Green, P. A., Gleeson, T., Eckman, S., Lehner, B., Balk, D., Boucher, T., Grill, G. and Montgomery, M. (2014) 'Water on an urban planet: Urbanization and the reach of urban water 
infrastructure', Global Environmental Change, 27, pp. 96-105. doi: 10.1016/j.gloenvcha.2014.04.022.

McKinsey (2014) Rethinking infrastructure: voices from the global infrastructure initiative. New York.

Morera, S., Comas, J., Poch, M. and Corominas, L. (2015) 'Connection of neighboring wastewater treatment plants: economic and environmental assessment', Journal of Cleaner Production. Elsevier Ltd, 90, pp. 34-42. doi: 10.1016/j.jclepro.2014.11.047.

Naik, K. S. and Stenstrom (2016) 'A Feasibility Analysis Methodology for Decentralized Wastewater Systems - Energy- efficiency and Cost', pp. 201-209. doi: 10.2175/106143016X14504669767337.

Nolde, E. (2012) 'Hohe Energie- und Wassereffizienz durch Grauwasserrecycling mit vorgeschalteter Wärmerückgewinnung', Fbr-Wasserspiegel, pp. 3-6. Available at: https://www.fbr.de/fileadmin/Daten/Artikel_aus_wsp/ArtikelArnimplatz_GW_fbr_1_13.pdf.

Nykvist, B. and Nilsson, M. (2015) 'Rapidly falling costs of battery packs for electric vehicles', Nature Climate Change, 5(4), pp. 329-332. doi: 10.1038/nclimate2564.

O'Flaherty, B. (2005) City Economics. Cambridge: Harvard University Press. OECD (1997) Glossary of Environment Statistics. Studies in Methods, Series F, No. 67. New York. Available at: https://stats.oecd.org/glossary/detail.asp?ID=2086. OECD (2006) Infrastructure to 2030 Telecom, Land Transport, Water and Electricity. doi: 10.1787/9789264023994-en.

OECD (2010) OECD Environmental Performance Reviews Japan. Paris, France: OECDpublishing. doi: 10.1787/9789264202887-en.

OECD (2015) Environment at a glance 2015 OECD indicators, OECD Publishing. doi: 10.1787/health_glance-2013-en.

Patterson, J. (1985) Industrial wastewater treatment technology. Second Edi. Butterworth Publishers, Stoneham, MA.

Peter-Varbanets, M., Zurbrügg, C., Swartz, C. and Pronk, W. (2009) 'Decentralized systems for potable water and the potential of membrane technology.', Water research, 43(2), pp. 245-65. doi: 10.1016/j.watres.2008.10.030.

Poustie, M. S., Deletic, A., Brown, R. R., Wong, T., de Haan, F. J. and Skinner, R. (2014) 'Sustainable urban water futures in developing countries: the centralised, decentralised or hybrid dilemma', Urban Water Journal, 12(7), pp. 1-16. doi: 10.1080/1573062X.2014.916725.

Prieto, Á. M., Zofío, J. L. and Álvarez, I. (2014) 'Cost economies, urban patterns and population density: The case of public infrastructure for basic utilities', Papers in Regional Science. doi: 10.1111/pirs.12096.

Sadoff, C. W., Hall, J. W., Grey, D., Aerts, J. C. J. H., Ait-Kadi, M., Brown, C., Cox, A., Dadson, S., Garrick, D., Kelman, J., McCornick, P., Ringler, C., Rosegrant, M., Whittington, D. and Wiberg, D. (2015) Securing Water, Sustaining Growth: Report of the GWP/OECD Task Force on Water Security and Sustainable Growth. Oxford. 
Sapkota, M., Arora, M., Malano, H., Moglia, M., Sharma, A., George, B. and Pamminger, F. (2016) 'An Integrated Framework for Assessment of Hybrid Water Supply Systems', Water, 8(1), p. 4. doi: 10.3390/w8010004.

Schiller, G. (2010) 'Cost Evaluation of the Adaptation of Waste Water Treatment Systems Under Shrinkage (Kostenbewer- tung der Anpassung Zentraler Abwasserentsorgungssysteme bei Bevölkerungs- rückgang)', IÖR Schriften 51. Berlin: Rhombos.

Schranner, T. (2014) 'Kleinkläranlagen bewähren sich in der Praxis', Korrespondenz Abwasser, Abfall, 61(8), pp. 695-700. doi: 10.3242/kae2014.08.003.

Shahabi, M. P., McHugh, A., Anda, M. and Ho, G. (2015) 'Comparative economic and environmental assessments of centralised and decentralised seawater desalination options', Desalination. Elsevier B.V., 376, pp. 25-34. doi: 10.1016/j.desal.2015.08.012.

Sharma, A. K., Tjandraatmadja, G., Cook, S. and Gardner, T. (2013) 'Decentralised systems - Definition and drivers in the current context', Water Science and Technology, 67(9), pp. 2091-2101. doi: 10.2166/wst.2013.093.

Siedentop, S. and Fina, S. (2010) 'Urban sprawl beyond Growth: The effect of demographic change on infrastructure costs', Flux, (79-80), pp. 90-100.

Spirandelli, D. (2015) 'Patterns of Wastewater Infrastructure along a Gradient of Coastal Urbanization: A Study of the Puget Sound Region', Land, 4(4), pp. 10901109. doi: 10.3390/land4041090.

Starkl, M., Parkinson, J., Narayana, D. and Flamand, P. (2012) 'Small is beautiful but is large more economical? Fresh views on decentralised versus centralised wastewater managment', WATER21, pp. 45-47.

Swiss Water Pollution Control Association (2006) VSA-Erhebung Kleinkläranlagen. Wolhusen, Switzerland.

Swisstopo (2015) 'swisstopo (Art. 30 GeolV): 5704000000 / TLM@2015, swissBoundaries3D@2015,(reproduced with permission of swisstopo / JA100119).'

Thomas, D. A. and Ford, R. R. (2005) The Crisis of Innovation in Water and Wastewater. Cheltenham, UK.: Edward Elgar Publishing.

Truffer, B., Binz, C., Gebauer, H. and Störmer, E. (2013) 'Market Success of On-site Treatment: A Systemic Innovation Problem', in Source Separation and Decentralization for Wastewater Management, pp. 209-223.

Truffer, B., Störmer, E., Maurer, M. and Ruef, A. (2010) 'Local strategic planning processes and sustainability transitions in infrastructure sectors', Environmental Policy and Governance, 20(4), pp. 258-269. doi: 10.1002/eet.550.

UN-WWAP (2015) The United Nations World Water Development Report 2015: Water for a Sustainable World. doi: 978-92-3-100071-3.

UN (2015) Environmental Indicators. Inland Water Resources, Wastewater. Available at: http://unstats.un.org/unsd/environment/wastewater.htm.

UN WWAP (2017) WWAP (United Nations World Water Assessment Programme). Available at: http://unesdoc.unesco.org/images/0024/002471/247153e.pdf. 
Unruh, G. (2000) 'Understanding carbon lock-in', Energy policy, 28(March), pp. 817830. doi: 10.1016/S0301-4215(00)00070-7.

UNSTATS (2016) Population density and urbanization. United Nations Statistics Devision. Available at: http://www.webcitation.org/6mqLJxLIR.

US-NRC (2012) Water Reuse - Potencial for Expanding the Nation's Supply Through Reuse of Municipal Wastewater. Washington, DC: The National Academies Press. doi: 10.17226/13303.

Vázquez-Rowe, I., Kahhat, R. and Lorenzo-Toja, Y. (2017) 'Natural disasters and climate change call for the urgent decentralization of urban water systems', Science of The Total Environment. Elsevier B.V., 605-606, pp. 246-250. doi: 10.1016/j.scitotenv.2017.06.222.

VSA (2016) Kleinkläranlagen. Available at: http://www.webcitation.org/6mkMt9iNW.

Weber, B., Cornel, P. and Wagner, M. (2007) 'Semi-centralised supply and treatment systems for (fast growing) urban areas', Water Science and Technology, 55(1-2), pp. 349-356. doi: 10.2166/wst.2007.021.

WERF (2018) When to consider distributed systems in an urban and suburban context. Available at:

http://www.werf.org/i/c/Decentralizedproject/When_to_Consider_Dis.aspx (Accessed: 30 May 2018).

West, C., Kenway, S., Hassall, M. and Yuan, Z. (2016) 'Why do residential recycled water schemes fail? A comprehensive review of risk factors and impact on objectives', Water Research. Elsevier Ltd, 102, pp. 271-281. doi: 10.1016/j.watres.2016.06.044.

Wickop (1998) 'Environmental quality targets for urban structural units in Leipzig with a view to sustainable urban development', in Breuste, J., Feldmann, H., UhImann, O. (Eds.), Urban Ecology. Springer, Berlin, Germany. doi: 10.1007/978-3-642-885839_7.

Wilderer, P. A., Grambow, M., Brenner, A., Bauer, W. P., Wilderer, P. A. and Grambow, M. (2016) 'Sanitary Engineering: Central or Decentral Solutions?', in Wilderer, P. A. and Grambow, M. (eds) Global Stability through Decentralization? In Search for the Right Balance between Central and Decentral Solutions. Springer, pp. 139-164. doi: 10.1007/978-3-319-24358-0_5.

Wilderer, P. A. and Schreff, D. (2000) 'Decentralized and centralized wastewater management: A challenge for technology developers', Water Science and Technology, 41(1), pp. 1-8. Available at: http://iwaponline.com/content/ppiwawst/41/1/1.full.pdf.

Yang, X. M., Morita, A., Nakano, I., Kushida, Y. and Ogawa, H. (2011) 'History and Current Situation of Night Soil Treatment Systems and Decentralized Wastewater Treatment Systems in Japan', Water Practice \& Technology, 5(4), pp. 1-18. doi: 10.2166/wpt.2010.096.

Zeferino, J. A., Cunha, M. C. and Antunes, A. P. (2012) 'Robust optimization approach to regional wastewater system planning.', Journal of Environmental Management, 109, pp. 113-122. doi: 10.1016/j.jenvman.2012.05.008. 
1236 Zodrow, K. R., Li, Q., Buono, R. M., Chen, W., Daigger, G., Duenas-Osorio, L., 1237 Elimelech, M., Huang, X., Jiang, G., Kim, J.-H., Logan, B. E., Sedlak, D. L.,

1238 Westerhoff, P. and Alvarez, P. J. J. (2017) 'Advanced Materials, Technologies, and 1239 Complex Systems Analyses: Emerging Opportunities to Enhance Urban Water 1240 Security', Environmental Science \& Technology, p. acs.est.7b01679. doi:

1241 10.1021/acs.est.7b01679. 